\title{
Novel Bio-Chemical Profiling of Indian Black Teas with Reference to Quality Parameters
}

\section{B.B. Borse* and L. Jagan Mohan Rao}

Plantation Products, Spices and Flavour Technology Department, Central Food Technological Research Institute, (Council of Scientific and Industrial Research), Mysore -570 020, India

\begin{abstract}
Novel bio-chemical profiling of Indian black teas covering all the regions and seasons ( $\mathrm{s}_{1}$ :April-June, $\mathrm{s}_{2}$ :JulySept., $s_{3}$ :Oct.-Dec., $s_{4}$ :Jan.- Mar.) from select gardens cutting across all climatic conditions so as to represent the variables was carried out. The profiling was carried out with reference to physico-bio-chemical quality indices based on parameters as well as volatiles and non-volatiles which are important from quality viewpoint. Different fingerprint markers in terms of volatiles and non-volatiles for tea quality were identified. Seasonal variation of TF/TR ratio over tea producing region/grade and with respect to quality was deliniated. Also the seasonal variation of sum of Yamanishi-Botheju and Mahanta ratio over tea producing region/grade and concomitant tea quality profile has been deliniated. The sum of TF/TR ratios of tea and the sum of the VFC ratios (Yamanishi-Botheju ratio and Mahanta ratio) added together is proposed for the first time as a new and novel quality index, hence forth referred to as BorseRao quality index, considered to be an overall quality indicator of tea as both the non-volatiles and volatiles are given due consideration. By using this quality index, seasonal variations of the tea quality over the producing regions/ grades in all the four seasons $\left(\mathrm{s}_{1}, \mathrm{~s}_{2}, \mathrm{~s}_{3}, \mathrm{~s}_{4}\right)$ were carried out. Accordingly based on the Borse-Rao quality index, tea can be categorized as good (upto 1), better (>1-4) and best (>4) quality tea respectively.
\end{abstract}

Keywords: Black tea; Profile; Fingerprint; Physical and bio-chemical parameters; Theaflavin (TF); Thearubigin (TR); Volatile flavour compounds; Yamanishi-Botheju ratio; Mahanta ratio; Borse-Rao quality index

\section{Introduction}

Tea is one of the most important plantation crops and it is very vital to know the physico-chemical and biochemical characteristics of tea which will serve as a fingerprint. Tea is grown in a wide range of climate, altitude and soil conditions. Considering the number of variables, it is very vital to have authentic scientific information on the tea aptly called as fingerprinting or profiling of tea. The data on the chemical, physical and biochemical constituents and variations in them will greatly help in getting a wealth of information (knowledge) that can be termed as finger print of tea. It is proposed to have such a fingerprinting on Indian black teas. The importance of profiling of Indian black teas was realized and work is carried out in this direction. This paper describes the results of investigations carried out in this area.

The world productin of Crush - Tear - Curl (CTC) tea was 1194 million Kgs, and orthodox tea production was 839 million Kgs during 1999 [1]. India is a leading tea producer, consumer and exporter with 928 million $\mathrm{Kg}$ production during 2005 and during 2007 it went up to 945 million $\mathrm{Kg}$. Black tea, manufactured from young tender shoots of Camellia sinensis (L.) O. Kuntze is the most widely enjoyed non-alcoholic drink and its flavour quality and taste has been shown to change with variations in geographical $[2,3]$ and climatic [4,5] conditions. Yamanishi et al. [3] compared flavour of teas from different parts of the world, while Cloughley et al. [4] compared flavour of teas in different season in Malawi, Africa. Indian teas, especially from Darjeeling, Assam and Nilgiris (Trinitea) are valued for their characteristic aroma and taste. These teas are much sought after and are relished by the beverage consumers throughout the world [6]. Several reports are available about antioxidant, anticancer properties and health benefits of tea [7-11].
The important chemical constituents, which influence the taste and flavour in tea brew are polyphenols, caffeine, sugars, organic acids, volatile flavour compounds and amino acids. Phenolic compounds of tea such as theaflavins and thearubigins are very important from intrinsic quality point of view. These are responsible for the colour, flavour and brightness of tea. Caffeine is responsible for the briskness. The physico-chemical parameters such as TSS and viscosity of the brew and bulk density (packed/loose) of the tea are important quality indicators. The volatile flavour compounds of tea and their variation in composition due to geographical and other process variables is of paramount importance from the quality point of view. Though considerable work was reported [12-14] on the quality aspects of tea, a comparative study covering Indian regions has not been done so far. Keeping in view the complexity of the intrinsic tea quality a study has been carried out to fingerprint the Indian black teas obtained from different regions. The data generated based on these studies will help to trace back the origin of the teas.

The standards prescribed for tea by different standards organizations such as ISO, BIS and PFA are the purity standards. These standards do not provide information about the intrinsic quality. The intrinsic quality of tea depends on number of variable and non-variable factors. Some of the factors can be controlled. With the result the intrinsic qualities of tea vary considerably.

*Corresponding author: B.B. Borse, Plantation Products, Spices and Flavour Technology Department, Central Food Technological Research Institute, (Council of Scientific and Industrial Research), Mysore - 570 020, India, Tel: +91-821-2512352; Fax: +91-821-2517233; E-mail: borsebb@cftri.org, bbborase@yahoo.com

Received April 13, 2012; Accepted April 28, 2012; Published April 30, 2012

Citation: Borse BB, Jagan Mohan Rao L (2012) Novel Bio-Chemical Profiling of Indian Black Teas with Reference to Quality Parameters. J Bioequiv Availab S14. doi:10.4172/jbb.S14-004

Copyright: (C) 2012 Borse BB, et al. This is an open-access article distributed under the terms of the Creative Commons Attribution License, which permits unrestricted use, distribution, and reproduction in any medium, provided the original author and source are credited. 
India grows tea in 38700 gardens spread in South, North and North-East States comprising of several regions of variable climate, soil, rainfall, altitude and latitude. This obviously has an effect on the intrinsic quality of tea. The manufacturing practices and methods further add up to the variations to the quality of tea. Though, the literature on intrinsic qualities of tea is available the information is scattered and is unorganized. Besides, there are no systematic investigations reported on profiling or fingerprinting of Indian black teas.

This paper reports the data on fingerprinting of Indian Black Teas from various regions of India in different seasons, which includes the analyses of physico-chemical parameters as well as biochemical components viz., Physico-chemical characteristics such as moisture, viscosity, total soluble solids, bulk density, caffeine, phenolic constituents (i.e., theaflavins and thearubigins) and volatile flavour compounds (VFC) of tea.

Roberts and Smith [15] have described a method for determination of polyphenolic oxidation products in black tea liquors for the assessment of quality in tea. Biswas and Biswas [16] also reported about the briskness of liquor and intrinsic quality evaluation. Further, Biswas et al. [17] reported that theaflavin is associated with all the liquor characters, i.e., colour, brightness, strength, briskness and quality. The thearubigins mostly contribute to the body of the liquor. Ullah [18] has critically discussed some of the intrinsic quality parameters and liquor characters of black tea. Mahanta [19] had reviewed the chemical basis of liquor characteristics based on the influence of pigments and processing conditions of black tea manufacture. Owuor and Obanda [20] have critically discussed the changes in quality of the South African black teas.

The changes in climate, altitude, the location, the processing, packaging and several other factors will have significant influences on the quality of tea. The use of sophisticated techniques for chemical and biochemical analysis will help to determine the changes in flavour profile at molecular levels in order to get data in defining the intrinsic quality of tea to serve as its fingerprint. The composite of biochemical constituents responsible for strength, taste, colour and flavour is elucidated so as to generate a fingerprint of Indian black teas.

\section{Materials and Methods}

\section{Materials}

In India, tea cultivation is spread over the hilly and plain areas of North, South and North-East. Tea is also grown in Kangra valley, Kumaon Hills and Ranchi. In South India, tea is cultivated in Western Ghats of Kerala, Nilgiris of Tamilnadu and Karnataka. The important tea growing regions of South India are: 1. Nilgiris, 2. Nilgiris-WaynadMysore, 3. Anamallais, 4. High range, 5. Central Travancore, 6. South Travancore; The Main three tea growing regions in North and NorthEast India are: 1.Darjeeling and Dooars (Darjeeling), 2. Brahmaputra valley (Assam), 3.Surma valley (Palampur).

\section{Collection of samples}

Organoleptically acceptable samples were selected cutting across all Indian tea producing regions and different parts of the year (seasons). The regions, parts of season and gardens were so selected as to represent a range of climatic, topographical, agronomical, processing and management factors. Samples of tea from the following Regions (gardens) spread over four seasons ( $s_{1}$ : April-June; $s_{2}$ : JulySeptember; $\mathrm{s}_{3}$ :October-December; $\mathrm{s}_{4}$ :January-March) of the year were collected (Figure 1): 1.Parajulie (Tamilnadu), 2.Pandiar (Tamilnadu), 3.AFTL (Assam - A AFTL), 4.Magor (Assam - A Mag), 5.Darjeeling premium (DP), 6.Darjeeling medium (DM), 7.Chinchula (Dooars), 8.Aibheel (Dooars), 9.Nilgiris (Tamilnadu), 10.Cachar best (Assam), 11.Cachar medium (Assam), 12.Palampur $G_{1}\left(P_{1}\right)$ - (Surma valley), 13.Palampur $\mathrm{G}_{2}\left(\mathrm{PG}_{2}\right)$ - (Surma valley), 14.Assam BOP, 15.Assam

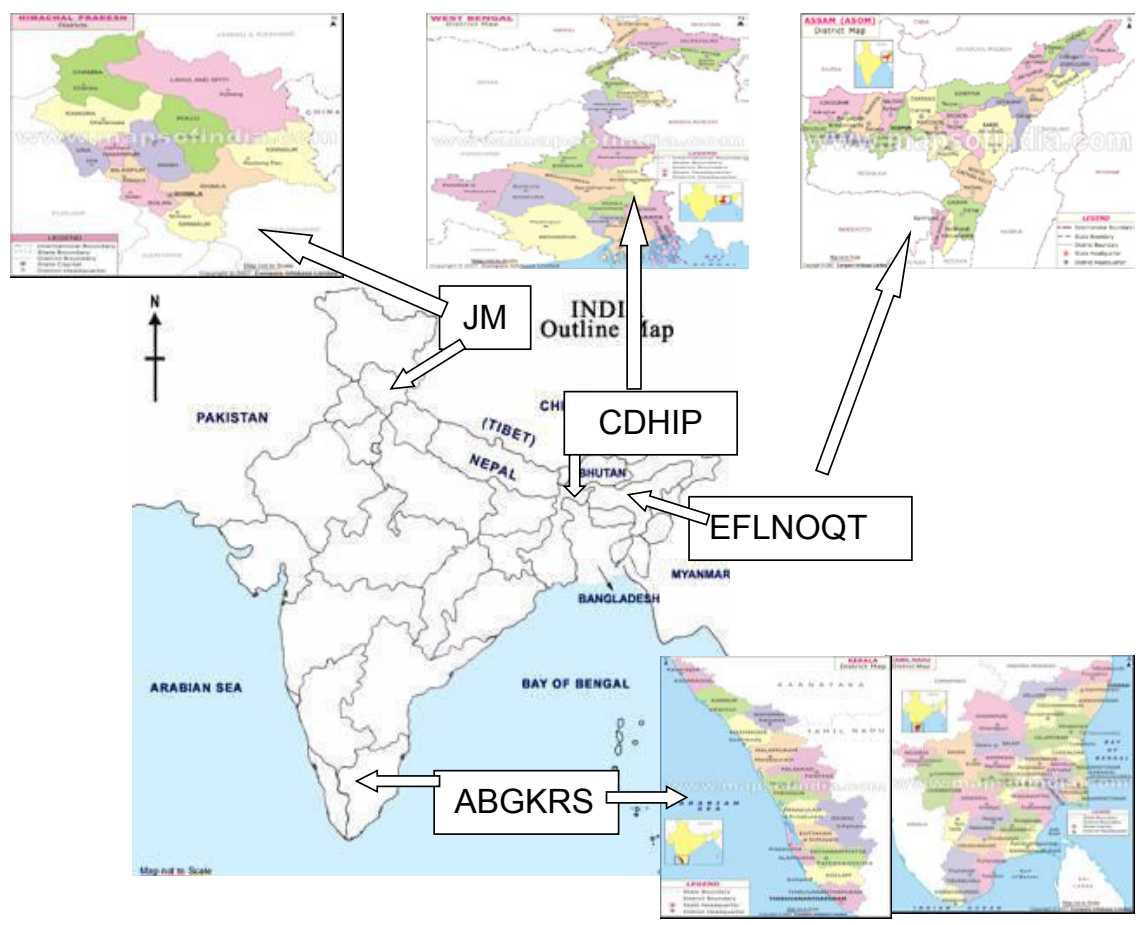

\begin{tabular}{|l|c|}
\hline Region / Grade / Garden & Code \\
\hline Tamilnadu, Parajulie & A \\
\hline Tamilnadu, Pandiar & B \\
\hline Darjeeling Medium & C \\
\hline Darjeeling Premium & D \\
\hline Assam AFTL & E \\
\hline Assam Magor & F \\
\hline Nilgiris HG & G \\
\hline Dooars, Aibheel & H \\
\hline Dooars, Chinchula & I \\
\hline Palampur G1 & J \\
\hline Nilgiris HG-CTC & K \\
\hline Dibrugarh, Rose kandy & L \\
\hline Palampur G2 & M \\
\hline Assam, Cachar best & N \\
\hline Assam, Cacher Med. & O \\
\hline Darjeeling, Kurti & P \\
\hline Assam BOP & Q \\
\hline Nilgiris Waynad & R \\
\hline Annamalai & S \\
\hline Assam OP & T \\
\hline
\end{tabular}

Figure 1: Tea samples - collection locations. 
OP, 16.Nilgiris high grown (Nil Hg) - (Tamilnadu), 17.Nilgiris high grown CTC-BOP (Nil Hg CTC) - (Tamilnadu), 18.Nilgiris Waynad (Tamilnadu), 19.Annamalai - (Tamilnadu), 20. Rosekandy (Dibrugarh - Assam), 21.Kurti (Darjeeling).

\section{Methods}

Analysis of physico-chemical characteristics such as Moisture, Viscosity of liquor, Total soluble solids, Bulk density, Colour of liquor and Brightness was carried out for all the tea samples. Quantitative determination for major volatile flavour compounds such as n-Hexanal, Leaf aldehyde, Leaf alcohol, trans/cis-2 Hexenol, n-Hexanol, n-Heptanal, Benzaldehyde, Nonanal, Linalool, Methyl salicylate and $\beta$-ionone, etc. Quantitative estimation of samples for caffeine, theaflavins, thearubigins and colour was also carried out.

\section{Determination of moisture}

It is the measurement of the quantity of moisture present in the tea sample apart from dry matter present (21). Tea sample was dried to a constant weight at $100-106^{\circ} \mathrm{C}(\sim 6 \mathrm{~h})$ in a hot air oven (Lynx, Lawrence and Mayo, India). The loss in weight of sample is noted as moisture and percentage of moisture content calculated on dry weight basis (DB).

\section{Determination of viscosity of tea liquor}

Measurement of viscosity of tea liquor may provide some basis for the body of the liquor. The viscosity in milli Pascals can be measured using viscometer directly [22].

Tea sample ( $2 \mathrm{~g}$ ) was added to a beaker containing boiling distilled water $(140 \mathrm{ml})$ and boiling continued for 4 mins. Brew filtered using Whatman No.5 filter paper under vacuum. Brew $(30 \mathrm{ml})$ was placed under the spindle of the viscometer (Rheology international Ltd., Shennon, Ireland) and by trial and error selected a suitable spindle keeping the RPM constant. Readings were noted in triplicate and average of the readings was taken as final viscosity of the tea brew.

\section{Determination of total soluble solids}

The total soluble solids content which contributes to the characteristic taste and body of a cup of tea apart from other constituents was determined. It is the measure of the soluble solids that dissolve in water upon brewing of the tea [23].

Tea sample ( $2 \mathrm{~g}$ ) was added to a beaker containing boiling distilled water $(140 \mathrm{ml})$ and the boiling was continued for 4 mins. Brew filtered using Whatman No.5 filter paper under vacuum and used. The value for total soluble solids of brew was recorded using a refractometer (Atago, Japan) at $20^{\circ} \mathrm{C}$. The average value of three readings was taken as TSS (\%).

\section{Determination of bulk density}

Bulk density indicates the weight of substance held in a unit volume and gives idea on cuppage and packaging of tea [24].

The tea sample was filled upto $500 \mathrm{ml}$ level in a glass cylinder using a hopper suspended $3 \mathrm{~cm}$ away from it. Weight of the tea sample noted. The weight of tea per unit volume $(\mathrm{g} / \mathrm{ml})$ is 'loose bulk density'.

The tea sample was filled upto $500 \mathrm{ml}$ level in a glass cylinder using a hopper suspended $3 \mathrm{~cm}$ away from it. Filled cylinder was tapped five times the cylinder using soft rubber tubing. The weight and volume of tea is noted. Weight of tea per unit volume $(\mathrm{g} / \mathrm{ml})$ is the 'compacted bulk density'.

\section{Estimation of soluble caffeine in tea by HPLC method}

Caffeine is an alkaloid present in tea to the extent of 1-5\%. Chemically it is trimethyl xanthine. The amount of water-soluble caffeine in tea brew is less than the total caffeine content of tea and was estimated [25]. Standard stock solution was prepared by dissolving $80 \mathrm{mg}$ caffeine (Sigma-Aldrich chemie GMBH, Steinheim, Germany) in $100 \mathrm{ml}$ water. Working standard was prepared by diluting $10 \mathrm{ml}$ of stock solution to $100 \mathrm{ml}$ to give a concentration of $0.08 \mu \mathrm{g} / \mu \mathrm{l}$. Working standard solution was analysed on HPLC (Shimadzu LC-6A and system controller SCL6A) equipped with the $\mu$ - Bondapak $C_{18}$ column $(3.9 \mathrm{~mm} \times 15 \mathrm{~cm}$, Waters, Milford,USA), using the mobile phase (Acetonitrile: water = 20:80 v/v) at a flow rate of $1 \mathrm{ml} / \mathrm{min}$. Detection was made by a UVvisible spectrophotometric detector (SPD-6AV) set at a sensitivity of 0.08 AUFS and wavelength of $276 \mathrm{~nm}$. Working standard solution (5$25 \mu \mathrm{l})$ was injected on the HPLC after initial equilibrium time (10 min), and peak area responses were obtained. A standard graph (Calibration Curve) for caffeine was prepared by plotting concentration versus area.

Black tea (2 g) weighed into a $250 \mathrm{ml}$ beaker and $177 \mathrm{ml}$ of boiling water was added, brewed for 6 min on boiling water bath $\left(80^{\circ} \mathrm{C}\right)$ filtered the brew through Whatman No.44 filter paper and $2 \mathrm{ml}$ filtrate was subjected to analysis for caffeine content. A SEP-PAK C ${ }_{18}$ cartridge (Millipore, Waters Associates, Maple Street/Milford, MA, USA) was activated by first passing methanol $(2 \mathrm{ml})$, followed by double distilled water ( $2 \mathrm{ml}$ ) by means of a glass syringe. Tea extract (brew, $2 \mathrm{ml}$ ) was then passed through the cartridge and elute was rejected. Air was passed to expel any remaining water. Caffeine was eluted from the cartridge with $6 \mathrm{ml}$ of chloroform (drop by drop), into an evaporating flask. The chloroform was removed on a water bath under vacuum. The residue in the flask was dissolved in the water and made upto $4 \mathrm{ml}$. An aliquot (5-10 $\mu \mathrm{l}$ ) of this solution was analysed on the HPLC under the earlier conditions (described for standard caffeine solution). The percent caffeine is calculated by comparing the peak area responses with standard caffeine curve (Calibration curve).

Spectrophotometric analysis of theaflavins (TFs) and thearubigins (TRs), Total colour and Brightness Biochemical assessment of black tea quality was done from estimation of TFs and TRs of tea brew. A rapid procedure for estimating theaflavins and thearubigins of black tea was adopted [26]. The absorbances were measured on a UV-visible spectrometer, Cintra 10 (Australia). The tea sample ( $9 \mathrm{~g}$ ) added to $375 \mathrm{ml}$ of boiling water in a conical flask and the boiling continued for $10 \mathrm{~min}$ using an air condenser on a water bath. The tea infusion was filtered through cotton cloth and cooled to room temperature. The infusion $(6 \mathrm{ml})$ was mixed with $6 \mathrm{ml}$ of $1 \%$ $(w / v)$ aqueous solution of anhydrous disodium hydrogen phosphate and the mixture extracted with $10 \mathrm{ml}$ of ethyl acetate by quick repeated inversion for $1 \mathrm{~min}$. The separated bottom layer drained, remaining was the ethyl acetate layer (the TF fraction) and diluted with $5 \mathrm{ml}$ ethyl acetate. Optical densities, $\mathrm{E}_{1}, \mathrm{E}_{2}, \mathrm{E}_{3}$; were obtained on extracts prepared as follows: $\mathrm{E}_{1}$ - TF extract $(10 \mathrm{ml})$ were diluted to $25 \mathrm{ml}$ with methanol; $\mathrm{E}_{2}$ - Infusion $(1 \mathrm{ml})$ diluted to $10 \mathrm{ml}$ with water and made up to $25 \mathrm{ml}$ with methanol; $\mathrm{E}_{3}$ - Infusion $(1 \mathrm{ml})$ was mixed with aqueous oxalic acid $(10 \% \mathrm{w} / \mathrm{v}, 1 \mathrm{ml})$, and water $(8 \mathrm{ml})$ and made up to $25 \mathrm{ml}$ with methanol; Optical densities of $E_{1}, E_{2}$, and $E_{3}$ were measured at 380 and $460 \mathrm{~nm}$.

$$
\begin{aligned}
& \text { At } 380 \mathrm{~nm} \\
& \% \mathrm{TF}=2.25 \mathrm{XE}_{1} ; \% \mathrm{TR}=7.06\left(4 \mathrm{E}_{3}-\mathrm{E}_{1}\right) \\
& \text { At } 460 \mathrm{~nm}
\end{aligned}
$$$$
\text { Total colour }=6.25 \mathrm{X} 4 \mathrm{E}_{2} ; \% \text { Brightness }=\mathrm{E}_{1} / 4 \mathrm{E}_{2} \mathrm{X} 100
$$ 


\section{HPLC profile of theaflavins}

Theaflavins (TFs) and Thearubigins (TRs) are the enzymatic oxidation products of tea flavanols which are formed during manufacture of tea. Black tea brew subjected to HPLC analysis for profiling of these compounds [27]. Black tea (4 g) was taken in boiling water $(100 \mathrm{ml})$ and infused for $10 \mathrm{~min}$ on water bath at $80^{\circ} \mathrm{C}$. Brew was filtered through whatman No.5 filter paper using Buchner funnel by applying vacuum and volume was made up to $100 \mathrm{ml}$ with double distilled water and used for HPLC analysis. The sample solution was analysed on HPLC (Shimadzu LC-6A) equipped with the $\mu$-Bondapak $\mathrm{C}_{18}$ column $(3.9 \mathrm{~mm} \times 15 \mathrm{~cm}$, Waters, Milford, USA) using the mobile phase [A $-1 \%$ citric acid solution ( $\mathrm{pH}$ adjusted to 2.8 using $\mathrm{NaOH}$ ); B - Acetonitrile; Gradient, linear $8 \%$ to $31 \%$ B (organic) in A over 50 $\mathrm{min}$ ] at a flow rate of $1.5 \mathrm{ml} / \mathrm{min}$. Detection was by a photodiode array detector, SPD-M10 AVP at wavelengths $280,380,460 \mathrm{~nm}$, softwareclass 10 (Shimadzu, Kyoto, Japan) communication bus moduleCBM-10A. By comparing the retention time responses with literature values the Theaflavins $\left(\mathrm{TF}_{\mathrm{s}}\right)$ were evaluated and classified according to Retention times [27].

\section{Isolation for volatile flavour compounds (vfcs) from black tea}

Flavour Compounds (VFCs) are the volatiles from black tea which are responsible for characteristic aroma of the black tea (Group-I and II, VFCs). Simultaneous distillation and solvent extraction (SDE), using a Likens-Nickerson apparatus [28] for isolation of volatiles, was carried out. Black tea sample (50 g) was added to a 2 Liter roundbottom flask containing 1 Liter distilled water, along with $0.2 \mathrm{ml}$ of internal standard ( $15 \mu \mathrm{l}$ of cumene in $10 \mathrm{ml}$ of petroleum ether). Into another flask $(200 \mathrm{ml}), 25 \mathrm{ml}$ of petroleum ether $\left(40-50^{\circ} \mathrm{C}\right.$ fraction), $0.25 \mathrm{ml}$ of ethanol and $25 \mathrm{ml}$ of diethyl ether with magnetic bit were placed. These two R.B. flasks were attached to two arms of the LikensNickerson apparatus and extracted for $2.5 \mathrm{~h}$. After extraction the solvent containing VFCs was evaporated on a water bath to $0.5 \mathrm{ml}$ volume, which was then transferred to a test tube and stored at $4^{\circ} \mathrm{C}$ for GC-MS analysis.

\section{GC-MS analysis for VFCs}

A Shimadzu GC-17A equipped with QP-5000 (Quadrupole) mass spectrometer was used. A fused silica capillary column SPB TM-1, coated with polydimethylsiloxane of $30 \mathrm{~m}$ length and $0.32 \mathrm{~mm}$ internal diameter and film thickness $0.25 \mu \mathrm{m}$, was used. Helium was the carrier gas with a flow rate of $1 \mathrm{ml} / \mathrm{min}$. Split ratio was $1: 50$ and ionisation voltage was $70 \mathrm{eV}$. The injection port temperature and detector port temperature were maintained at $220^{\circ} \mathrm{C}$. Oven temperature programme was: $40^{\circ} \mathrm{C}$ (3) $-2^{\circ} \mathrm{C} / \mathrm{min}, 100^{\circ} \mathrm{C}-4^{\circ} \mathrm{C} / \mathrm{min}, 220^{\circ} \mathrm{C}$ [7]; a sample of $1 \mu \mathrm{l}$ was injected for each analysis. Total ion chromatogram (TIC) for the samples and mass spectrum of each peak are obtained. Identification of compounds was achieved by comparison of mass spectra reported (NIST library, [29]) and Kovats indices [30,31].

Kovat's Index $=$

$$
100 N+100 n \frac{\left[\log t_{R}(A)-\log t_{R}(N)\right]}{\left[\log t_{R}(N+n)-\log t_{R}(N)\right]}
$$

where:

$\mathrm{t}_{\mathrm{R}}(\mathrm{A})=$ Retention Time $(\mathrm{RT})$ of unknown compound peak.

$t_{R}(N)=R T$ of smaller hydrocarbon eluted before the compound peak.
$\mathrm{t}_{\mathrm{R}}(\mathrm{N}+\mathrm{n})=\mathrm{RT}$ of larger hydrocarbon eluted after the compound peak.

$\mathrm{N}=$ Carbon number of smaller standard hydrocarbon.

$(\mathrm{N}+\mathrm{n})=$ Carbon number of larger standard hydrocarbon .

Amount of Unknown =

$\frac{\text { Area Response of Unknown }}{\text { Area Response of Standard }} \times$ Weight of Standard

Calculation of terpene index, mahanta ratio, yamanishi botheju - ratio and borse - rao quality index

The basic aroma characteristics are probably due to different varieties of tea plants as well as the influence of specific growing conditions. To identify the varietal origin of individual teas, Takeo and Mahanta [2] proposed a terpene index (TI), which is defined as:

$$
\text { Terpene Index }=\frac{\text { Linalool }+ \text { Linalool derivatives }}{\text { Linalool }+ \text { Linalool derivatives }+ \text { geraniol }}
$$

The terpene index of pure variety sinensis approaches zero whereas the TI of pure var. assamica approaches unity.

A ratio based on the sum of gas chromatographic peak areas of terpenoids to non-terpenoids [32,33] called Mahanta ratio was developed. The terpenoids were assumed to be desirable while the nonterpenoids were classified as undesirable to tea aroma and quality.

$$
\text { Mahanta ratio }=\frac{\text { Terpenes }(\text { desirable })}{\text { Non }- \text { terpenes }(\text { Undesirable })}
$$

Yamanishi et al. [34] developed another ratio based on gas chromatographic peak areas of linalool and E-2-hexenal, which ignored all other VFC. This ratio is known as Yamanishi-Botheju ratio. The rationale for the use of Yamanishi-Botheju ratio requires that linalool and E-2-hexenal occur in large amounts in all teas and therefore may have a dominant effect.

$$
\text { Yamanishi }- \text { Boteju ratio }=\frac{\text { Linalool }}{E-2-\text { Hexenal }}
$$

A new approach in terms of novel quality index for tea has been innovated and proposed through this work. The sum of TF/TR ratios of tea and the sum of the VFC ratios (Yamanishi-Botheju ratio and Mahanta ratio) added together is proposed for the first time as a new and novel quality index, hence forth referred to as 'Borse-Rao quality index', considered to be an overall quality indicator of tea as both the non-volatiles/volatiles are given due consideration in this quality index.

\section{Results and Discussion}

Samples were selected cutting across all Indian tea producing regions and four seasons. The regions, seasons and gardens were so selected as to represent a range of climatic, topographical, agronomical, processing and management factors. Samples of tea from the given regions/gardens spread over four seasons of the year (April-June, JulySept., Oct.-Dec., Jan.- March) were procured, studies were carried out for fingerprinting. The results are presented below in terms of regional and seasonal fingerprint.

\section{Profiling of the tea samples from first season (April- June)}

The results of the analyses of the physico-chemical parameters for the black tea samples from Season-1 (April-June) are presented in Table 1. Moisture content in teas varied from 3.5\% to $8.2 \%$. The total 
Citation: Borse BB, Jagan Mohan Rao L (2012) Novel Bio-Chemical Profiling of Indian Black Teas with Reference to Quality Parameters. J Bioequiv Availab S14. doi:10.4172/jbb.S14-004

Page 5 of 16

\begin{tabular}{|c|c|c|c|c|c|c|c|c|c|c|}
\hline \multirow{2}{*}{ Sample } & \multirow{2}{*}{ Caffeine* $\left.^{*} \%\right)$} & \multirow{2}{*}{$\begin{array}{l}\text { TSS } \\
(\%)\end{array}$} & \multirow{2}{*}{$\begin{array}{c}\text { Viscosity } \\
\text { (mPa) }\end{array}$} & \multirow{2}{*}{$\begin{array}{c}\text { Moisture } \\
\text { (\%) }\end{array}$} & \multicolumn{2}{|c|}{ Bulk density (g/ml) } & \multirow{2}{*}{$\begin{array}{l}\text { TF } \\
(\%)\end{array}$} & \multirow{2}{*}{$\begin{array}{l}\text { TR } \\
\text { (\%) }\end{array}$} & \multirow{2}{*}{$\begin{array}{l}\text { Total } \\
\text { colour }\end{array}$} & \multirow{2}{*}{$\begin{array}{c}\text { Brightness } \\
(\%)\end{array}$} \\
\hline & & & & & Loose & Packed & & & & \\
\hline Darj. Medium & 2.28 & 0.05 & 11.3 & 8.27 & 0.25 & 0.31 & 0.25 & 8.37 & 2.36 & 9.03 \\
\hline ( \pm ) S.D. & 0.04 & 0.0 & 0.00 & 0.05 & 0.01 & 0.01 & 0.02 & 0.05 & 0.09 & 0.02 \\
\hline Darj. Premium & 3.36 & 0.05 & 11.40 & 6.47 & 0.26 & 0.34 & 0.24 & 8.58 & 1.33 & 9.90 \\
\hline ( \pm ) S.D. & 0.03 & 0.0 & 0.0 & 0.06 & 0.01 & 0.01 & 0.03 & 0.03 & 0.04 & 0.05 \\
\hline Parajulie & 1.65 & 0.25 & 8.6 & 3.53 & 0.39 & 0.44 & 0.42 & 13.69 & 3.85 & 6.81 \\
\hline ( \pm ) S.D. & 0.01 & 0.0 & 0.0 & 0.10 & 0.01 & 0.01 & 0.04 & 0.10 & 0.09 & 0.07 \\
\hline Pandiar & 2.63 & 0.15 & 8.6 & 4.13 & 0.37 & 0.43 & 0.43 & 11.91 & 2.59 & 12.57 \\
\hline$( \pm)$ S.D. & 0.06 & 0.0 & 0.0 & 0.02 & 0.01 & 0.01 & 0.05 & 0.08 & 0.06 & 0.08 \\
\hline Assam AFTL & 4.03 & 0.1 & 4.1 & 6.87 & 0.38 & 0.36 & 1.50 & 15.06 & 4.78 & 24.73 \\
\hline ( \pm )S.D. & 0.03 & 0.0 & 0.0 & 0.04 & 0.0 & 0.01 & 0.05 & 0.06 & 0.04 & 0.02 \\
\hline Assam Magor & 4.09 & 0.15 & 10.8 & 6.87 & 0.36 & 0.39 & 1.72 & 13.54 & 6.09 & 25.85 \\
\hline ( \pm ) S.D. & 0.08 & 0.0 & 0.0 & 0.02 & 0.0 & 0.01 & 0.06 & 0.08 & 0.02 & 0.10 \\
\hline Aibheel & 2.46 & 0.25 & 10.8 & 5.13 & 0.38 & 0.42 & 1.15 & 14.78 & 4.96 & 21.49 \\
\hline ( \pm ) S.D. & 0.05 & 0.0 & 0.0 & 0.08 & 0.01 & 0.0 & 0.02 & 0.02 & 0.01 & 0.08 \\
\hline Chinchula & 3.00 & 0.25 & 12 & 7.93 & 0.42 & 0.45 & 0.91 & 14.81 & 4.77 & 16.26 \\
\hline ( \pm S.D. & 0.01 & 0.0 & 0.0 & 0.03 & 0.01 & 0.01 & 0.05 & 0.06 & 0.02 & 0.04 \\
\hline Cachar Med & 2.58 & 0.15 & 7.4 & 7.07 & 0.37 & 0.41 & 0.69 & 11.29 & 3.88 & 15.08 \\
\hline$( \pm)$ S.D. & 0.08 & 0.0 & 0.0 & 0.02 & 0.01 & 0.01 & 0.03 & 0.01 & 0.09 & 0.09 \\
\hline Cachar Best & 3.01 & 0.25 & 4.1 & 5.07 & 0.35 & 0.39 & 0.50 & 11.63 & 3.46 & 12.01 \\
\hline$( \pm)$ S.D. & 0.01 & 0.0 & 0.0 & 0.02 & 0.01 & 0.01 & 0.01 & 0.04 & 0.03 & 0.06 \\
\hline Nil-HG & 2.51 & 0.25 & 11 & 6.07 & 0.31 & 0.38 & 0.50 & 9.37 & 1.63 & 16.97 \\
\hline ( \pm ) S.D. & 0.01 & 0.0 & 0.0 & 0.10 & 0.01 & 0.0 & 0.03 & 0.06 & 0.08 & 0.07 \\
\hline
\end{tabular}

Values expressed are mean \pm S.D. of five experiments; * Soluble caffeine

Table 1: Season 1 (April- June) - Physico chemical analysis of black tea samples.

soluble solids were determined using Atago refractometer. The total soluble solids varied from 0.05 to $0.25 \%$. Teas from Parajulie, Niligiri high grown, Aibheel, Chinchula and Cachar best had highest total soluble solids of $0.25 \%$ each. Teas from Pandiar, Assam Magor and Cachar medium had moderate total soluble solids of $0.15 \%$ each. Tea from Assam AFTL alone had lower TSS of $0.1 \%$. Teas from Darjeeling (Premium and Medium) had lowest TSS of $0.05 \%$ each. It is clear from these results that some of the teas from North and South have good TSS content $0.25 \%$ and few have moderate of $0.15 \%$, whereas the Darjeeling teas can be characterized by their lowest TSS of $0.05 \%$.

The soluble caffeine content in the samples varied from 1.65 to 4.09\%. Assam AFTL and Assam Magor samples contained highest soluble caffeine 4.03 and 4.09 percent. Darjeeling premium, Chinchula and Cachar best teas also contained high soluble caffeine 3.35, 3.21 and 3.01 percent respectively. Pandiar, Darjeeling medium, Nilgiris high grown, Aibheel and Cachar medium teas had moderate quantities of soluble caffeine $2.63,2.28,2.51,2.46$ and $2.58 \%$ respectively. Only teas from Parajulie had the lowest soluble caffeine content of $1.65 \%$. It can be seen that Assam teas have the highest caffeine content and so the briskness. Also the best teas or quality teas had 2 to $3 \%$ of soluble caffeine content.

Viscosity of the brew varied from 4.1 to 12 milli Pascals. Tea brew from Chinchula alone had highest viscosity $12 \mathrm{mPa}$ and Darjeeling (Medium and Premium), Nilgiri high grown, Assam Magor and Aibheel had medium viscosity $11.3,11.4,11.0,10.8$ and $10.8 \mathrm{mPa}$ respectively. Tea brews from Parajulie and Pandiar had viscosity 8.6 $\mathrm{mPa}$ each and Cachar medium tea brew had viscosity of $7.4 \mathrm{mPa}$. The brew from Assam AFTL and Cachar best had lowest viscosity $4.1 \mathrm{mPa}$. Darjeeling teas' brews showed very good amount of viscosity even though they looked thin.
Bulk density (BD) varied from 0.25 to $0.42 \mathrm{~g} / \mathrm{ml}$ (Loose $\mathrm{BD}$ ) and 0.31 to $0.45 \mathrm{~g} / \mathrm{ml}$ (Packed BD). Darjeeling (Premium and Medium) and Nilgiri high grown teas have lowest loose bulk densities $(0.25,0.26$ and $0.31 \mathrm{~g} / \mathrm{ml})$ as well as compacted bulk densities $(0.31,0.34$ and $0.38 \mathrm{gm} /$ $\mathrm{ml})$. Chinchula tea had the highest loose and packed BD (0.42 and 0.45 $\mathrm{g} / \mathrm{ml})$.

The results of analysis for theaflavins, thearubigins, total colour and brightness for black tea samples from season-1(April-June) are presented in Table 1 and figure 2 (HPLC profile). It is evident from the results (Method 3.8) that theaflavin (TF) content varied from 0.24 to $1.72 \%$. Darjeeling teas can be characterized by lowest TF of 0.24 and

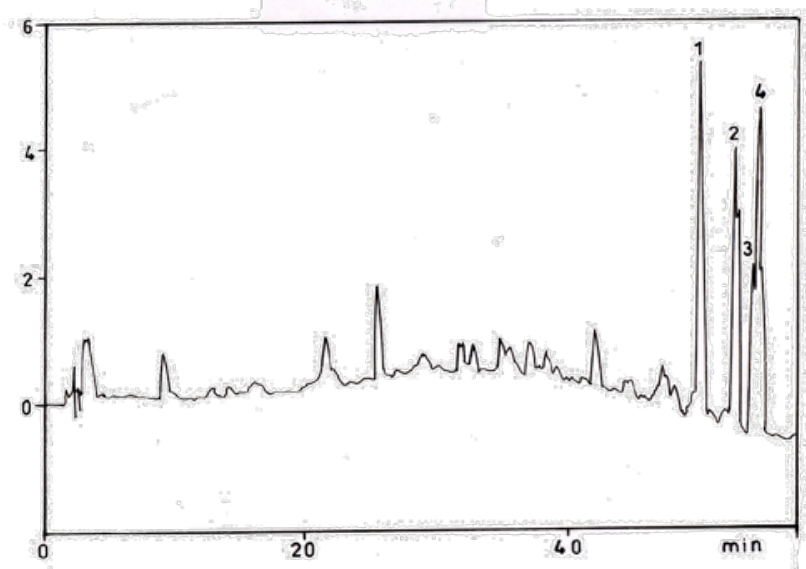

Peaks: 1 = theaflavin; 2 = theaflavin-3-gallate; 3 = theaflavin-3'-gallate; $4=$ theaflavin-3.3'-digallate

Figure 2: HPLC chromatogram of tea 
Citation: Borse BB, Jagan Mohan Rao L (2012) Novel Bio-Chemical Profiling of Indian Black Teas with Reference to Quality Parameters. J Bioequiv Availab S14. doi:10.4172/jbb.S14-004

Page 6 of 16

$0.25 \%$ whereas Assam AFTL and Assam Magor can be characterized by highest TF of 1.5 and $1.72 \%$ respectively. But Nilgiris high grown possesses almost double the TF content compared to Darjeeling. Other south Indian teas (Parajulie, Pandiar $-0.42 \%$ and $0.43 \%$ ) had lower TF content as compared to North Indian teas (Aibheel (1.15\%), Chinchula (0.91\%), Cachar medium (0.69) and Cachar best (0.50\%).

The results indicate that thearubigin (TR) content ranged from 8.37\% to $15.06 \%$. Assam AFTL (15.06\%), Aibheel (14.78\%) and Chinchula (14.81\%) had highest TR content. Parajulie and Assam Magor had TR content $13.69 \%$ and $13.54 \%$ respectively. Cachar teas (Medium and Best) and pandiar teas had moderate TR content of $11.29 \%, 11.63 \%$ and $11.91 \%$ respectively. Darjeeling (Medium and Premium) teas can be marked with lowest TR content of $8.37 \%$ and $8.56 \%$ and Niligiri high grown by slightly higher content of TR $(9.37 \%)$ than Darjeeling.

The results indicate that Assam Magor have highest total colur (6.09) and brightness (25.85\%). Assam AFTL (4.78, 24.73\%), Aibheel (4.96, 21.49\%), Chinchula $(4.77,16.26 \%)$ had the high total colour and brightness values, when compaed to Cachar teas, which have moderate total colour (3.88 and 3.46) and brightness (15.08\% and $12.01 \%$ ). Parjulie and Pandiar have total colour 3.85 and 2.59 respectively. Parajulie has the lowest brightness (6.81\%) and Pandiar has almost double the brightness as to Parajulie (12.57\%). Darjeeling premium can be marked with lowest total colour (1.33) and brightness (9.90\%). But Darjeeling medium has total colour slightly highest (2.36) and brightness lower (9.03) than premium. Nilgiri high grown tea can be marked by lower total colour (1.63) and moderate brightness (16.97\%).

Volatile flavour compounds were isolated and Identification of compounds was achieved by comparison mass spectra (NIST library,
29) and Kovats indices [30,31] Twenty-five volatile flavour compounds (VFCs) are identified and taken as markers and presented Table 2. Their quantities were calculated with reference to internal standard in different tea samples. The teas from different origins can be marked by the composition of VFCs identified. Gulati and Ravindranath [12] explained seasonal variation of the VFCs in Kangra teas. Gulati et al. [13] studied the aroma profiles with respect to clonal variations in Kangra teas. Ullah [14] studied aroma constituents, of Assam and China hybrid teas and their manifestation during tea processing. $\mathrm{He}$ identified eight aroma constituents, concluding that aroma constituents of tea are mainly inherent in the leaf and their manifestation is largely governed by black tea processing methods.

The results of the fingerprinting with regard to VFC for season-1 (April-June) are presented in Table 3 and Figure 3. It is clear from the results that:

1.Darjeeling premium quality tea possesses highest quantity (13.49 $\mathrm{mg} \%$ ) of total volatiles, where as Cacher best has lowest $(3.18 \mathrm{mg}$ $\%)$. Darjeeling medium quality, parajulie and Pandiar contained higher amounts of total volatiles.

2.Darjeeling teas contained highest $\mathrm{n}$-hexanal (1241-3702 $\mu \mathrm{g} / 100 \mathrm{~g})$ and leaf alcohol $(967-1018 \mu \mathrm{g} / 100 \mathrm{~g})$.

3.Darjeeling premium quality tea can be marked by the presence of nonanol $(60-70 \mu \mathrm{g} / 100 \mathrm{~g})$.

4.Nilgiris high grown can be marked by absence of phenyl ethanol and highest content of linalool $(2345 \mu \mathrm{g} / 100 \mathrm{~g})$ and methyl salicylate $(721 \mu \mathrm{g} / 100 \mathrm{~g})$

5.Parajulie can be marked by highest content of Nerolidol (160 -

\begin{tabular}{|c|c|c|c|c|}
\hline S.No & Compound & $\mathrm{KI}$ cal & $\mathrm{M}^{+}$ & $\mathrm{m} / \mathrm{z}$ \\
\hline 1 & n-Hexanal & 772 & 100 & $41,55,42,69,57$ \\
\hline 2 & E- 2- hexenal & 825 & 98 & $41,42,55,69,57$ \\
\hline 3 & Z-3- Hexenol & 842 & 100 & $41,67,82,55,69$ \\
\hline 4 & 2-hexenol & 848 & 100 & $57,82,41,43,44$ \\
\hline 5 & n-hexanol & 853 & 102 & $56,43,41,55,42$ \\
\hline 6 & n-heptanal & 875 & 114 & $43,41,70,44,55$ \\
\hline 7 & Cumene & 911 & 120 & $105,120,77,51,79$ \\
\hline 8 & Benzaldehyde & 939 & 106 & $77,106,105,51,50$ \\
\hline 9 & $(E, Z)-2,4-H e p t a d i e n a l$ & 975 & 110 & $81,41,53,67,110$ \\
\hline 10 & $(E, E)-2,4$-Heptadienal & 984 & 110 & $81,41,53,67,110$ \\
\hline 11 & Nonanal & 1006 & 142 & $41,57,43,55,56$ \\
\hline 12 & Phenyl acetaldehyde & 1017 & 120 & $91,65,92,120,51$ \\
\hline 13 & Benzyl alcohol & 1022 & 108 & $79,108,77,107,1$ \\
\hline 14 & cis-Linalooloxide & 1058 & 170 & $59,43,55,94,68$ \\
\hline 15 & trans- Linalooloxide & 1073 & 170 & $59,43,55,94,68$ \\
\hline 16 & Linalool & 1085 & 154 & $71,41,93,55,43$ \\
\hline 17 & Phenyl ethyl alcohol & 1097 & 122 & $91,92,65,122,51$ \\
\hline 18 & a-terpineol & 1173 & 154 & $59,43,93,81,121$ \\
\hline 19 & Methyl salicylate & 1180 & 152 & $120,92,152,121,65$ \\
\hline 20 & cis-Geraniol & 1232 & 154 & $41,69,93,67,53$ \\
\hline 21 & Indole & 1291 & 117 & $117,89,90,63,118$ \\
\hline 22 & Geranyl acetate & 1358 & 196 & $41,43,69,68,67$ \\
\hline 23 & $\beta$-Ionone & 1455 & 192 & $177,43,41,44,178$ \\
\hline 24 & Dihydroactinidiolide & 1471 & 180 & $111,43,109,137,67$ \\
\hline 25 & Nerolidol & 1518 & 222 & $41,69,43,93,71$ \\
\hline 26 & Phytol & 2010 & 296 & $71,43,57,69,123$ \\
\hline
\end{tabular}

Table 2: Identification of major volatile flavour compounds from black tea. 
Citation: Borse BB, Jagan Mohan Rao L (2012) Novel Bio-Chemical Profiling of Indian Black Teas with Reference to Quality Parameters. J Bioequiv Availab S14. doi:10.4172/jbb.S14-004

Page 7 of 16

\begin{tabular}{|c|c|c|c|c|c|c|c|c|c|c|c|c|}
\hline $\begin{array}{l}\text { SI. } \\
\text { No. }\end{array}$ & Compound name & $\begin{array}{l}\text { Darjeel } \\
\text { Premi. }\end{array}$ & $\begin{array}{l}\text { Darjeel } \\
\text { Medim. }\end{array}$ & Parajulie & Pandiar & $\begin{array}{l}\text { Assam } \\
\text { AFTL }\end{array}$ & $\begin{array}{l}\text { Assam } \\
\text { Magor }\end{array}$ & Aibheel & Chinchula & $\begin{array}{c}\text { Cachar } \\
\text { best }\end{array}$ & $\begin{array}{c}\text { Cachar } \\
\text { med. }\end{array}$ & $\begin{array}{l}\text { Nilgiris } \\
\text { HG }\end{array}$ \\
\hline 1 & n-hexanal & 3702 & 1241 & 562 & 448 & 257 & 203 & 293 & 89 & 50 & 149 & A \\
\hline 2 & Leaf aldehyde (E-2-hexenal) & 3436 & 1692 & 3136 & 5912 & 2478 & 6088 & 799 & 1677 & 2133 & 4312 & 958 \\
\hline 3 & Leaf alcohol (Z-3-hexenol) & 1018 & 967 & 560 & 740 & 34 & 223 & 154 & 236 & 158 & 151 & 662 \\
\hline 4 & trans / cis-2-hexenol & 168 & 531 & A & 183 & $\mathrm{~T}$ & 86 & 40 & 62 & 50 & 63 & 115 \\
\hline 5 & n-hexenol & 151 & 459 & 25 & 320 & $\mathrm{~T}$ & 49 & 44 & 158 & 138 & $\mathrm{~T}$ & 91 \\
\hline 6 & n-heptanal & 58 & 320 & 185 & 169 & 100 & 133 & 55 & 64 & 38 & 95 & 63 \\
\hline 7 & Benzaldehyde & 254 & 216 & 204 & $\mathrm{~T}$ & 122 & 57 & 62 & 57 & 49 & 92 & 73 \\
\hline 8 & $(E, Z)-2,4$-Heptadienal & 27 & $\mathrm{~T}$ & 185 & $\mathrm{~T}$ & $\mathrm{~T}$ & 14 & 18 & $\mathrm{~T}$ & $\mathrm{~T}$ & $\mathrm{~T}$ & 12 \\
\hline 9 & $(E, E)-2,4$-Heptadienal & 37 & $\mathrm{~T}$ & 185 & $\mathrm{~T}$ & $\mathrm{~T}$ & 63 & 62 & $T$ & $T$ & $\mathrm{~T}$ & 19 \\
\hline 10 & Nonanal & 66 & A & A & A & $\mathrm{T}$ & $\mathrm{T}$ & $\mathrm{T}$ & $\mathrm{T}$ & A & $\mathrm{T}$ & A \\
\hline 11 & Phenyl acetaldehyde & 310 & 928 & 951 & 355 & 836 & 716 & 898 & 682 & 330 & 2061 & 322 \\
\hline 12 & Benzyl alcohol & 310 & 77 & 31 & 577 & 252 & 111 & 157 & 150 & 0 & 147 & 68 \\
\hline 13 & cis-linalool oxide & 516 & 805 & 142 & $\mathrm{~T}$ & 44 & 55 & 128 & 29 & $\mathrm{~T}$ & 65 & 268 \\
\hline 14 & trans-linalool oxide & 890 & 1611 & 574 & 128 & 29 & 95 & 427 & 90 & 27 & 206 & 1136 \\
\hline 15 & Linalool & \multirow{3}{*}{1166} & \multirow{3}{*}{2052} & 1642 & 128 & 103 & 48 & 54 & $\mathrm{~T}$ & $\mathrm{~T}$ & 206 & 2345 \\
\hline 16 & Phynyl ethyl alcohol & & & 25 & 137 & 166 & 35 & 602 & 112 & 28 & 286 & A \\
\hline 17 & 4-terpineol & & & $A$ & 579 & 199 & 173 & 0 & 112 & 78 & 540 & $A$ \\
\hline 18 & a-terpineol & 165 & 270 & 154 & $\mathrm{~T}$ & 131 & 51 & 157 & 48 & 19 & 92 & 80 \\
\hline 19 & Methyl salicylate & 314 & 475 & 130 & 180 & 96 & 76 & 145 & 50 & 40 & 212 & 721 \\
\hline 20 & Nerol & & 44 & & & 18 & & 26 & 36 & & & A \\
\hline 21 & cis-Geraniol & 723 & 987 & 43 & 369 & 19 & 17 & 44 & & $\mathrm{~T}$ & $\mathrm{~T}$ & 14 \\
\hline 22 & Geranyl acetate & 46 & 110 & 37 & $\mathrm{~T}$ & 20 & 26 & 19 & A & $\mathrm{T}$ & 32 & 35 \\
\hline 23 & $\beta$-lonone & 57 & 54 & 278 & 76 & 20 & 20 & 70 & 34 & 26 & 103 & 42 \\
\hline \multirow[t]{5}{*}{24} & Nerolidol & 76 & 87 & 179 & $\mathrm{~T}$ & 52 & 17 & 26 & 31 & 12 & 55 & 101 \\
\hline & Total & 13490 & 12926 & 9228 & 10301 & 4976 & 8356 & 4280 & 3717 & 3176 & 8867 & 7125 \\
\hline & Terpene Index & 0.78 & 0.81 & 0.98 & 0.41 & 0.90 & 0.92 & 0.93 & 1.0 & 1.0 & 1.0 & 0.99 \\
\hline & Yamanishi Botheju ratio & 0.34 & 1.21 & 0.52 & 0.02 & 0.04 & 0.007 & 0.07 & - & - & 0.05 & 2.44 \\
\hline & Mahanta ratio & 0.41 & 1.10 & 0.60 & 0.16 & 0.20 & 0.07 & 0.60 & 0.15 & 0.06 & 0.27 & 2.01 \\
\hline
\end{tabular}

Values expressed are mean of three experiments, Where $A=A b s e n t, T=$ Trace

Table 3: Season 1(April- June)- Black tea samples-volatile flavour compounds (VFC) $\mu \mathrm{g} / 100 \mathrm{~g}$.

$200 \mu \mathrm{g} / 100 \mathrm{~g})$ and $\mu$ - ionone $(260-300 \mu \mathrm{g} / 100 \mathrm{~g})$ and absence of trans/cis-2-hexanol.

6.Pandiar can be characterized with highest content of benzyl alcohol $(560-590 \mu \mathrm{g} / 100 \mathrm{~g})$ and trace of benzaldehyde, and higher content of leaf aldehyde $(5900-5930 \mu \mathrm{g} / 100 \mathrm{~g})$.

7.Assam AFTL and Assam Magor can be characterized by lowest $\mu$ - ionone content $(20 \mu \mathrm{g} / 100 \mathrm{~g})$

8.Assam AFTL has only trace of Trans/cis -2-hexanol and Assam Magor has highest content of leaf aldehyde (6070 - 6100 $\mu \mathrm{g} / 100 \mathrm{~g})$.

9.Chinchula tea can be marked by the absence of geranyl acetate and Aibheel by lowest content of geranyl acetate $(19 \mu \mathrm{g} / 100 \mathrm{~g})$.

10.Chinchula and Aibheel can be marked by trace and lower ( 54 $\mu \mathrm{g} / 100 \mathrm{~g}$ ) content of linalool

11.Cachar Best and medium can be characterized by trace of both heptadienals and traces of nerol and cis-geraniol.

12.Cachar Best has lowest content of $n$-hexanal ( $50 \mu \mathrm{g} / 100 \mathrm{~g})$, while it is absent in Nilagiri high grown.
Terpene index, Yamanishi-Botheju ratio and Mahanta ratio for the volatile flavour compounds are calculated and presented in table 3. The terpene indices of Chinchula, Cachar Best and medium teas are unity and indicating these to be pure assamica varieties, where as that of Nilgiris high grown, parajulie, Aibheel, Assam AFTL and Assam

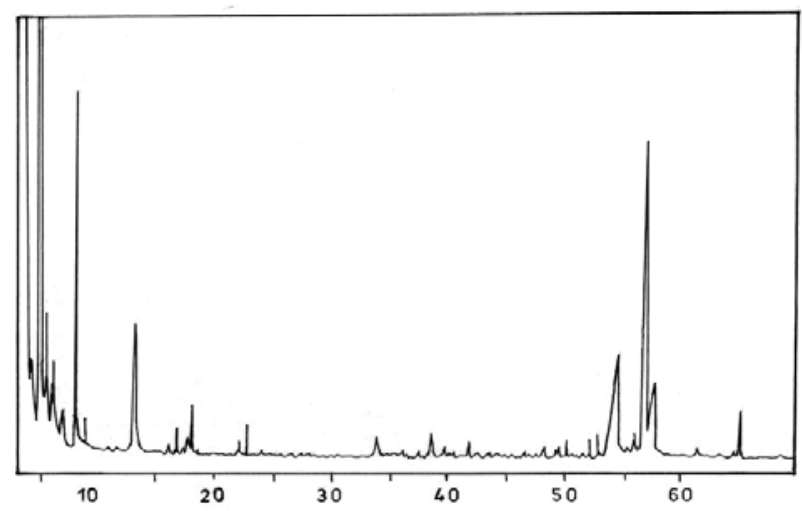

Figure 3: Total ion chromatogram of black tea volatiles (VFC). 
Citation: Borse BB, Jagan Mohan Rao L (2012) Novel Bio-Chemical Profiling of Indian Black Teas with Reference to Quality Parameters. J Bioequiv Availab S14. doi:10.4172/jbb.S14-004

Page 8 of 16

Magor are approaching unity $(0.90-0.99)$ and indicating these to be hybrids dominated by assamica. Darjeeling premium and medium quality, pandiar teas are found to be hybrids of assamica and sinensis, from their terpene indices $(0.78,0.81$ and 0.41 respectively).

Nilgiris high grown tea showed highest Mahanta ratio for VFCs indicating the presence of more quantities of desirable VFC, which indicate better quality of flavour. Darjeeling premium and medium, parajulie and Aibheel teas are of moderate quality with regard to flavour. Teas from Pandiar, Assam AFTL and Assam Magor, Chinchula, Cachar Best and medium possess lowest Mahanta ratio and an indication that flavour is low. Yamanishi-Botheju ratios also support the above findings.

Profiling of the tea samples from second season (JulySeptember)

The results of the physico-chemical analyses for the black tea samples from season-2 (July-september) are presented in Table 4. It is clear from the results that the moisture content varied from 3.2 to 6.4\% and TSS content (Method 2.3.2.3) ranged from 0.05 to $1.0 \%$. Tea brews from Palampur $\mathrm{G}_{1}$ contained highest TSS (1.0\%), followed by Rosekandy (0.6\%) and and Nilgiris high grown CTC BOP (0.4\%). Tea brews from Parajulie, Nilgiris high grown, Aibheel and Chinchula contained moderate TSS $0.25 \%$ each. Tea brew from Pandiar contained TSS $0.15 \%$. Tea brew from Assam AFTL and Assam Magor had lower TSS of $0.10 \%$. Darjeeling (medium/premium) tea can be marked by lowest TSS of $0.05 \%$ in its brew.

The soluble caffeine content varied from 1.91 to $3.84 \%$. Assam AFTL contained highest soluble caffeine (3.84\%) followed by Palampur
$\mathrm{G}_{1}(3.69 \%)$ Rosekandy (3.46\%) Assam Magor (2.74\%) and Chinchula $(2.72 \%)$. Darjeeling medium (2.6\%), Niligiris high grown $(2.43 \%)$, Darjeeling best (2.31\%), Aibheel (2.29\%) and Parajulie (2.26\%) teas contained moderate soluble caffeine. Nilgiris high grown CTC-BOP and Pandiar teas had lowest soluble caffeine (2.08 \% and 1.91\%).

Determination of viscosity of the tea liquor (Method 2.3.2.2) was done with a view that it may provide information about body of the tea liquor. The viscosity ranged from 6.3 to $12.80 \mathrm{~m} \mathrm{~Pa}$. It was again noted that Darjeeling best tea brew had highest viscosity $12.80 \mathrm{~m} \mathrm{~Pa}$ and Nilgiris high grown CTC-BOP had lowest viscosity $6.3 \mathrm{~m} \mathrm{~Pa}$.

The bulk densities ranged from 0.24 to $0.46 \mathrm{~g} / \mathrm{ml}$. The packed (compacted) bulk density of Darjeeling teas (Medium and Premium, 0.30 and $0.34 \mathrm{~g} / \mathrm{ml}$ respectively) as well as loose bulk density (Medium and Premium, 0.24 and $0.25 \mathrm{~g} / \mathrm{ml}$ respectively) is lowest compared to other teas. Teas from Aibheel and Nilgiris high grown CTC-BOP have the highest packed $(0.46 \mathrm{~g} / \mathrm{ml})$ and highest loose $(0.42$ and $0.40 \mathrm{~g} / \mathrm{ml})$ bulk densities.

The results of the fingerprinting with reference to theaflavins, thearubigins, total colour and brightness for black tea samples from season-2 (July-Sept.) are presented in Table 4 and figure 2.

It is evident from the results that theaflavin (TF) content varied from 0.10 to $1.02 \%$. Assam AFTL has the highest TF (1.02\%), besides Rosekandy (0.88\%) Nilgiris high grown CTC-BOP (0.80\%), Assam Magor (0.78\%) and Pandiar (0.77\%). Aibheel (0.64\%), Parajulie (0.62\%), Chinchula $(0.62 \%)$ and Niligiri high grown $(0.60 \%)$ have moderate $\mathrm{TF}$ content. Darjeeling premium (0.51\%), Darjeeling medium $(0.20 \%)$ and Palampur $\mathrm{G}_{1}(0.10 \%)$, can be marked with lowest TF conent.

\begin{tabular}{|c|c|c|c|c|c|c|c|c|c|c|}
\hline \multirow[t]{2}{*}{ Sample } & \multirow{2}{*}{$\begin{array}{c}\text { Soluble } \\
\text { Caffeine } \\
(\%)\end{array}$} & \multirow{2}{*}{$\begin{array}{l}\text { TSS } \\
(\%)\end{array}$} & \multirow{2}{*}{$\begin{array}{l}\text { Viscosity } \\
(\mathrm{mPa})\end{array}$} & \multirow{2}{*}{$\begin{array}{l}\text { Moisture } \\
(\%)\end{array}$} & \multicolumn{2}{|c|}{$\begin{array}{c}\text { Bulk density } \\
(\mathrm{g} / \mathrm{ml})\end{array}$} & \multirow[t]{2}{*}{$\mathrm{TF}(\%)$} & \multirow[t]{2}{*}{ TR (\%) } & \multirow[t]{2}{*}{$\begin{array}{l}\text { Total } \\
\text { colour }\end{array}$} & \multirow[t]{2}{*}{$\begin{array}{c}\text { Brightness } \\
(\%)\end{array}$} \\
\hline & & & & & Loose & Packed & & & & \\
\hline Parajulie & 2.26 & 0.25 & 12.00 & 4.53 & 0.38 & 0.44 & 0.62 & 11.86 & 2.61 & 16.90 \\
\hline$( \pm)$ S.D. & 0.02 & 0.00 & 0.00 & 0.02 & 0.01 & 0.01 & 0.01 & 0.01 & 0.10 & 0.08 \\
\hline Pandiar & 1.91 & 0.15 & 12.00 & 4.93 & 0.38 & 0.42 & 0.77 & 6.88 & 1.90 & 19.41 \\
\hline ( \pm )S.D. & 0.04 & 0.00 & 0.00 & 0.01 & 0.01 & 0.0 & 0.01 & 0.02 & 0.03 & 0.09 \\
\hline Assam AFTL & 3.84 & 0.10 & 10.50 & 4.53 & 0.37 & 0.42 & 1.02 & 12.36 & 4.08 & 21.33 \\
\hline ( \pm )S.D. & 0.01 & 0.00 & 0.00 & 0.03 & 0.0 & 0.01 & 0.02 & 0.01 & 0.03 & 0.07 \\
\hline Assam Magor & 2.74 & 0.10 & 10.50 & 4.47 & 0.36 & 0.40 & 0.78 & 13.65 & 5.21 & 36.11 \\
\hline (士)S.D. & 0.02 & 0.00 & 0.00 & 0.01 & 0.01 & 0.01 & 0.01 & 0.02 & 0.01 & 0.04 \\
\hline Darj. Medium & 2.60 & 0.05 & 11.00 & 5.00 & 0.24 & 0.30 & 0.20 & 5.47 & 1.08 & 9.91 \\
\hline$( \pm)$ S.D. & 0.02 & 0.00 & 0.00 & 0.00 & 0.01 & 0.01 & 0.01 & 0.14 & 0.05 & 0.03 \\
\hline Darj. Premium & 2.31 & 0.05 & 12.80 & 6.07 & 0.25 & 0.34 & 0.51 & 8.30 & 1.92 & 17.25 \\
\hline$( \pm)$ S.D. & 0.03 & 0.00 & 0.00 & 0.02 & 0.01 & 0.01 & 0.00 & 0.02 & 0.01 & 0.07 \\
\hline Nil-HG & 2.43 & 0.25 & 10.70 & 4.80 & 0.30 & 0.38 & 0.60 & 6.61 & 1.43 & 21.59 \\
\hline$( \pm)$ S.D. & 0.03 & 0.0 & 0.0 & 0.0 & 0.01 & 0.01 & 0.01 & 0.03 & 0.07 & 1.05 \\
\hline Aibheel & 2.29 & 0.25 & 11.70 & 3.20 & 0.42 & 0.46 & 0.64 & 8.58 & 3.24 & 16.53 \\
\hline ( \pm )S.D. & 0.03 & 0.0 & 0.0 & 0.0 & 0.01 & 0.01 & 0.01 & 0.02 & 0.02 & 0.08 \\
\hline Chinchula & 2.72 & 0.25 & 10.50 & 4.13 & 0.42 & 0.45 & 0.62 & 9.54 & 3.19 & 15.12 \\
\hline$( \pm)$ S.D. & 0.02 & 0.0 & 0.00 & 0.12 & 0.00 & 0.01 & 0.01 & 0.03 & 0.03 & 0.05 \\
\hline PalampurG1 & 3.69 & 1.00 & 11.0 & 3.40 & 0.27 & 0.35 & 0.10 & 9.48 & 1.78 & 7.41 \\
\hline ( \pm S.D. & 0.05 & 0.01 & 0.01 & 0.02 & 0.01 & 0.02 & 0.01 & 0.01 & 0.01 & 0.03 \\
\hline Nil-HG-CTC-BOP & 2.08 & 0.40 & 6.30 & 6.40 & 0.40 & 0.46 & 0.80 & 14.82 & 3.85 & 16.27 \\
\hline 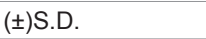 & 0.03 & 0.01 & 0.01 & 0.01 & 0.01 & 0.02 & 0.01 & 0.02 & 0.01 & 0.04 \\
\hline Rosekandy* & 3.46 & 0.60 & 8.50 & 6.40 & 0.36 & 0.41 & 0.88 & 12.46 & 4.85 & 16.57 \\
\hline$( \pm)$ S.D. & 0.06 & 0.01 & 0.01 & 0.02 & 0.02 & 0.01 & 0.02 & 0.02 & 0.03 & 0.01 \\
\hline
\end{tabular}

Values expressed are mean \pm S.D. of five experiments; * Dibrugarh, Assam

Table 4: Season 2 (July-September) - Physico-chemical analysis of black tea. 
Citation: Borse BB, Jagan Mohan Rao L (2012) Novel Bio-Chemical Profiling of Indian Black Teas with Reference to Quality Parameters. J Bioequiv Availab S14. doi:10.4172/jbb.S14-004

Page 9 of 16

Thearubigins (TR) content varied from 5.47 to $14.82 \%$. Nilgiris high grown CTC-BOP (14.82\%), Assam Magor (13.65\%), Rosekandy (12.46\%) and Assam AFTL (12.36\%) can be characterized by highest TR contents besides the highest TF content. Parajulie have slightly lower TR (11.86\%) than Assam teas. But Pandiar (6.72\%) and Nilgiris high grown (6.61\%) have much lower TR content. Aibheel (8.58\%), Chinchula (9.54\%) and Darjeeling best $(8.30 \%)$ had moderate TR content. But Darjeeling medium tea can be marked by lowest TR (5.47\%).

The results for total colour varied from 1.08 (Darjeeling medium) to 5.21 (Assam Magor). Interestingly the trend was found similar for brightness also i.e. 9.91\% (Darjeeling medium) to 36.11\% (Assam Magor). In sum total Assam Magor can be marked by highest colour and brightness whereas Darjeeling medium by lowest colour and brightness. Assam AFTL (4.08 and 21.23\%), Rosekandy (4.85, 16.57\%), Nilgiris high grown CTC-BOP (3.85 and 16.27\%), Aibheel (3.24 and $16.53 \%$ ) and Chinchula (3.19 and 15.12\%), had highest total colour and brightness followed by Assam Magor. South Indian teas Parajulie (2.61 and $16.90 \%)$ and Pandiar (1.89 and 19.41\%) along with Palampur $\mathrm{G}_{1}$ $(1.78,7.41 \%)$ had marginally more or less colour and brightness than Darjeeling teas. But Nilgiri high grown had less total colour (1.43) and more brightness (21.29\%) as compared to Darjeeling best (1.92 and $17.25 \%)$.

The results of fingerprinting with respect to volatile flavour compounds for season-2 (July-Sept.) are presented in Table 5 and figure 3. It is evident from the results that:

1.The total quantity of volatiles is in the range of $2.145-18.630$ $\mathrm{mg} / 100 \mathrm{~g}$ of tea sample during this season. Aibheel possesses highest quantity (18.63 $\mathrm{mg} \%$ ) of total volatiles, where as Nilgiri high grown CTC has lowest (2.15 mg\%). Palampur G1, Parajulie, Nilgiri high grown, Pandiar and Assam magor contained higher amounts of total volatiles. Content of phytol is not considered for total volatiles, as it is product derived from chlorophylls during degradation

2.Marker for Darjeeling (Medium/Premium) and Nilgiris high grown teas is absence of $\mu$ - ionone content and higher content of methyl salicylate $(519-761 \mu \mathrm{g} / 100 \mathrm{~g})$

3.Darjeeling teas can be marked by lower content of leaf aldehyde (708-736 $\mu \mathrm{g} / 100 \mathrm{~g})$ and lower to modest content of leaf alcohol (124-522 $\mu \mathrm{g} / 100 \mathrm{~g})$ and absence of both heptadienals and traces of nonanal

4.Palampur $\mathrm{G}_{1}$ and Nilgiris $\mathrm{HG}$ (non CTC) tea has highest and higher content of leaf alcohol $(2781 \mu \mathrm{g}$ and $728 \mu \mathrm{g} / 100 \mathrm{~g})$ and Nilgiris HG (non CTC) tea has highest content of linalool (2542 $\mu \mathrm{g} / 100 \mathrm{~g})$.

5.Parajulie and Pandiar can be marked by lowest content of

\begin{tabular}{|c|c|c|c|c|c|c|c|c|c|c|c|c|c|}
\hline $\begin{array}{l}\text { SI. } \\
\text { No. }\end{array}$ & Compound & Parajulie & Pandiar & $\begin{array}{l}\text { Darjeelg. } \\
\text { Medium }\end{array}$ & $\begin{array}{l}\text { Darjeel. } \\
\text { Premim }\end{array}$ & $\begin{array}{l}\text { Assam } \\
\text { AFTL }\end{array}$ & $\begin{array}{l}\text { Assam } \\
\text { Magor }\end{array}$ & $\begin{array}{c}\text { Nilgiris } \\
\text { HG }\end{array}$ & Aibheel & $\begin{array}{l}\text { Chinch- } \\
\text { ula }\end{array}$ & $\begin{array}{l}\text { Palam } \\
\text { pur G1 }\end{array}$ & $\begin{array}{l}\text { Nilgiris } \\
\text { HG-CTC }\end{array}$ & $\begin{array}{l}\text { Rose } \\
\text { kandy }\end{array}$ \\
\hline 1 & n-hexanal & 88 & 95 & 232 & 338 & 101 & 61 & 650 & 380 & 182 & A & 199 & 128 \\
\hline 2 & Leaf aldehyde (E2-hexenal) & 1307 & 1150 & 736 & 708 & 406 & 6024 & 755 & 3196 & 1444 & 3871 & 1230 & 2071 \\
\hline 3 & Leaf alcohol (Z-3-hexenol) & 136 & 160 & 522 & 124 & 314 & 118 & 728 & 543 & 140 & 2781 & 63 & 84 \\
\hline 4 & Trans / cis-2-hexenol & A & 62 & 134 & A & 73 & A & 192 & $T$ & $\mathrm{~T}$ & 272 & 43 & 48 \\
\hline 5 & n-hexenol & 57 & 58 & A & $\mathrm{T}$ & A & 891 & 272 & 163 & 47 & 565 & 50 & 44 \\
\hline 6 & n-heptanal & 85 & $A$ & 115 & 120 & $\mathrm{~T}$ & $\mathrm{~T}$ & A & $T$ & 752 & 147 & 47 & 55 \\
\hline 7 & Benzaldehyde & 143 & $T$ & 315 & 328 & 104 & 57 & 139 & 447 & 500 & 125 & 88 & 31 \\
\hline 8 & $(\mathrm{E}, \mathrm{Z})-2,4$-Heptadienal & $\mathrm{T}$ & A & A & A & A & A & A & A & A & 170 & A & $T$ \\
\hline 9 & $(\mathrm{E}, \mathrm{E})-2,4-H e p t a d i e n a l$ & 45 & $A$ & A & A & 22 & A & $\mathrm{T}$ & A & A & 275 & $A$ & 11 \\
\hline 10 & Nonanal & 73 & A & $\mathrm{T}$ & $\mathrm{T}$ & A & 57 & $\mathrm{~T}$ & 250 & 42 & 114 & A & A \\
\hline 11 & Phenyl acetaldehyde & 600 & 569 & 1076 & 914 & 783 & 891 & 419 & 5609 & 965 & 147 & 99 & 797 \\
\hline 12 & Benzyl alcohol & 67 & 193 & 229 & 119 & 130 & A & $\mathrm{T}$ & 1043 & 131 & 806 & 31 & $\mathrm{~T}$ \\
\hline 13 & Cis-linalool oxide & 77 & 252 & 1047 & 833 & 192 & 160 & 767 & 359 & 206 & 719 & 20 & 15 \\
\hline 14 & Trans-linalool oxide & 196 & A & 1516 & 1552 & 0 & 0 & 1614 & 0 & 0 & 1745 & 60 & 55 \\
\hline 15 & Linalool & 469 & 869 & 1510 & 1838 & $A$ & 528 & 2542 & 1326 & 500 & 1313 & 96 & A \\
\hline 16 & Phynyl ethyl alcohol & $\mathrm{T}$ & $A$ & $A$ & 533 & 556 & 0 & 575 & 2217 & 0 & 210 & & 122 \\
\hline 17 & Alfa-terpineol & $T$ & $T$ & A & A & A & A & 617 & A & $A$ & 455 & 17 & 10 \\
\hline 18 & Methyl salicylate & 99 & 314 & 761 & 519 & 146 & 168 & 614 & 1402 & 292 & 1495 & 47 & 40 \\
\hline 19 & Cis-Geraniol & 170 & 657 & 1764 & 1509 & 24 & 66 & 147 & 348 & 40 & 822 & 34 & 20 \\
\hline 20 & Geranyl acetate & $\mathrm{T}$ & A & 302 & 124 & $T$ & A & $\mathrm{T}$ & 206 & 93 & 181 & A & A \\
\hline 21 & $\beta$-Ionone & 182 & A & A & A & $\mathrm{T}$ & 123 & A & 902 & 203 & 47 & 6 & 14 \\
\hline 22 & Nerolidol & $T$ & 248 & A & A & A & A & A & A & A & 453 & A & 14 \\
\hline 23 & Phytol* $^{*}$ & 2164 & 7245 & A & A & 1768 & 9009 & 1386 & 27370 & 5572 & A & 256 & 589 \\
\hline 24 & Indole & A & A & A & A & A & A & A & 239 & A & $\mathrm{T}$ & 8 & 9 \\
\hline \multirow[t]{5}{*}{25} & dihydroactinidiolide & A & A & A & A & A & A & A & A & A & A & 7 & 10 \\
\hline & Total & 3794 & 4627 & 10259 & 9559 & 2851 & 9144 & 10031 & 18630 & 5537 & 16713 & 2145 & 3578 \\
\hline & Terpene Index & 0.81 & 0.63 & 0.69 & 0.73 & 0.89 & 0.91 & 0.97 & 0.82 & 0.94 & 0.82 & 0.83 & 0.77 \\
\hline & Yamanishi Botheju ratio & 0.36 & 0.75 & 2.05 & 2.59 & - & 0.08 & 3.36 & 0.41 & 0.34 & 0.33 & 0.07 & - \\
\hline & Mahanta ratio & 0.56 & 1.32 & 2.98 & 3.61 & 0.21 & 0.12 & 2.07 & 0.64 & 0.28 & 0.68 & 0.13 & 0.06 \\
\hline
\end{tabular}

* Phytol is not included in the total volatiles as well as in mahanta ratio (refer results and discussion for details)

@Values expressed are mean of three experiments, Where A=Absent, T= Trace

Table 5: Season 2 (July-September)- Black tea samples-volatile flavour compounds (VFC) $\mu \mathrm{g} / 100 \mathrm{~g}^{\circledR}$. 
Citation: Borse BB, Jagan Mohan Rao L (2012) Novel Bio-Chemical Profiling of Indian Black Teas with Reference to Quality Parameters. J Bioequiv Availab S14. doi:10.4172/jbb.S14-004

Page 10 of 16

$\mathrm{n}$-hexanal (88 -95 $\mu \mathrm{g} / 100 \mathrm{~g})$ and either absence or trace of phenyl ethyl alcohol.

6.Assam AFTL and Assam Magor can be marked by lowest content of hexanal (61-101 $\mu \mathrm{g} / 100 \mathrm{~g})$ and benzaldehyde (57 - 104 $\mu \mathrm{g} / 100 \mathrm{~g})$.

7.Assam magor can be marked by highest content of leaf aldehyde $(6024 \mu \mathrm{g} / 100 \mathrm{~g})$ and Assam AFTL by lowest content of cisgeraniol $(24 \mu \mathrm{g} / 100 \mathrm{~g})$ and (E,E)-2,4-heptadienal ( $22 \mu \mathrm{g} / 100 \mathrm{~g})$, besides above .

8.Aibheel and Chinchula can be marked by highest content of benzaldehyde (447 and $500 \mu \mathrm{g} / 100 \mathrm{~g}$ respectively) and highest content of phenyl acetaldehyde (5609 and $965 \mu \mathrm{g} / 100 \mathrm{~g}$ ) respectively.

9.Aibheel can be marked by highest $(27370 \mu \mathrm{g} / 100 \mathrm{~g})$ phytol and $\mu$ - ionone $(902 \mu \mathrm{g} / 100 \mathrm{~g})$ content.

10.Aibheel and Chinchula can be characterized by trace of translinalool oxide.

Terpene index, Yamanishi-Botheju ratio and Mahanta ratio for the volatile flavour compounds are calculated and presented in table 5 . The terpene indices of Niligiri high grown, Chinchula, Assam Magor teas are approaching to unity $(0.91-0.97)$ and indicating these to be dominated with assamica. Remaining teas are found to be hybrids of assamica and sinensis, from their terpene indices, which is in the range of $0.63-0.88$.

Darjeeling medium, Darjeeling premium and Nilgiris high grown teas showed highest Mahanta ratios (2.07-3.61) for VFCs indicating the presence of more quantities of desirable VFC, which indicate better quality of flavour during the second season. Pandiar, Parajulie, Palampur G1 and Aibheel teas showed medium Mahanta ratios (0.561.32) indicating moderate quality with regard to flavour during this season. Chinchula, Assam AFTL, Nilgiris high grown CTC, Assam Magor and Rosekandy possess lowest mahanta ratio and indicate flavour is low. Yamanishi-Botheju ratios of these teas also support the above findings.

\section{Profiling of the tea samples from third season (October- December)}

The results of the physico-chemical fingerprint for the black tea samples from season-3 (October-December) are presented in Table 6. The moisture content in teas varied from 2.8 to $7.7 \%$ and soluble caffeine content in tea brews of samples from third season ranged from 1.33 to $4.07 \%$. Aibheel (1.33\%) and Chinchula (1.39\%) tea brew had lowest and that of Darjeeling premium (4.07\%) had highest soluble caffeine content. Tea brews from Pandiar (3.94\%), Assam BOP (3.92\%), Palampur $\mathrm{G}_{2}$ (3.72\%), Kurti (3.54\%), Assam AFTL (3.37\%) and Parajulie $(3.15 \%)$, had slightly lower soluble caffeine contents compared to Darjeeling premium. Tea brews from Darjeeling Medium (2.96\%), Niligiri high grown (2.71\%) and Assam Magor (2.24\%) have the moderate soluble caffeine content.

The TSS in the tea brews during third season varied from 0.05 to 1.0\%. Palampur $\mathrm{G}_{2}(1.0 \%)$, Assam BOP $(0.8 \%)$ and Kurti $(0.6 \%)$ had higher TSS in tea brew. While Parjulie, Nilgiri high grown, Aibheel and Chinchula had moderate $(0.25 \%)$ TSS in tea brew; whereas tea brews from Pandiar, Assam AFTL and Assam Magor had lower TSS of 0.15\%. Darjeeling Medium and premium had lowest TSS (0.05\%) in tea brew.

\begin{tabular}{|c|c|c|c|c|c|c|c|c|c|c|}
\hline \multirow[t]{2}{*}{ Sample } & \multirow{2}{*}{$\begin{array}{c}\text { Soluble } \\
\text { Caffeine (\%) }\end{array}$} & \multirow[t]{2}{*}{ TSS (\%) } & \multirow[t]{2}{*}{ Viscosity (mPa) } & \multirow[t]{2}{*}{ Moisture (\%) } & \multicolumn{2}{|c|}{$\begin{array}{l}\text { Bulk density } \\
(\mathrm{g} / \mathrm{ml})\end{array}$} & \multirow{2}{*}{$\begin{array}{l}\text { TF } \\
(\%)\end{array}$} & \multirow{2}{*}{$\begin{array}{l}\text { TR } \\
(\%)\end{array}$} & \multirow{2}{*}{$\begin{array}{l}\text { Total } \\
\text { colour }\end{array}$} & \multirow{2}{*}{$\begin{array}{c}\text { Brightness } \\
(\%)\end{array}$} \\
\hline & & & & & Loose & Packed & & & & \\
\hline Parajulie & 3.15 & 0.25 & 11.9 & 4.86 & 0.38 & 0.42 & 0.74 & 12.27 & 2.76 & 16.18 \\
\hline \pm S.D. & 0.04 & 0.0 & 0.0 & 0.01 & 0.02 & 0.0 & 0.04 & 0.05 & 0.01 & 0.04 \\
\hline Pandiar & 3.94 & 0.15 & 10.4 & 5.0 & 0.38 & 0.42 & 0.61 & 8.55 & 1.83 & 18.92 \\
\hline (士)S.D. & 0.03 & 0.0 & 0.0 & 0.0 & 0.03 & 0.01 & 0.02 & 0.04 & 0.02 & 0.05 \\
\hline Assam AFTL & 3.37 & 0.15 & 10.2 & 7.0 & 0.39 & 0.45 & 1.36 & 16.29 & 4.90 & 23.46 \\
\hline$( \pm)$ S.D. & 0.01 & 0.0 & 0.0 & 0.0 & 0.0 & 0.0 & 0.07 & 0.06 & 0.03 & 0.03 \\
\hline Assam Magor & 2.24 & 0.15 & 10.3 & 4.8 & 0.37 & 0.42 & 1.86 & 15.24 & 6.56 & 26.97 \\
\hline$( \pm)$ S.D. & 0.01 & 0.0 & 0.0 & 0.0 & 0.01 & 0.02 & 0.05 & 0.03 & 0.04 & 0.02 \\
\hline Darj. Medium & 2.96 & 0.05 & 11.6 & 7.73 & 0.25 & 0.32 & 0.70 & 9.15 & 2.04 & 9.05 \\
\hline 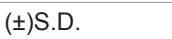 & 0.02 & 0.05 & 0.0 & 0.01 & 0.01 & 0.0 & 0.02 & 0.01 & 0.01 & 0.01 \\
\hline Darj. Premium & 4.07 & 0.05 & 11.8 & 6.06 & 0.25 & 0.33 & 0.29 & 8.00 & 2.06 & 11.85 \\
\hline$( \pm)$ S.D. & 0.02 & 0.0 & 0.0 & 0.01 & 0.03 & 0.01 & 0.02 & 0.02 & 0.03 & 0.03 \\
\hline Nil-HG & 2.72 & 0.25 & 11.1 & 5.06 & 0.25 & 0.32 & 0.54 & 8.42 & 1.38 & 18.58 \\
\hline$( \pm)$ S.D. & 0.02 & 0.0 & 0.0 & 0.01 & 0.0 & 0.02 & 0.03 & 0.04 & 0.04 & 0.05 \\
\hline Aibheel & 1.33 & 0.25 & 11.5 & 4.40 & 0.45 & 0.49 & 1.26 & 15.00 & 5.45 & 21.84 \\
\hline$( \pm)$ S.D. & 0.01 & 0.0 & 0.0 & 0.0 & 0.02 & 0.0 & 0.04 & 0.05 & 0.04 & 0.03 \\
\hline Chinchula & 1.39 & 0.25 & 10.3 & 5.80 & 0.42 & 0.46 & 0.98 & 16.80 & 5.23 & 17.03 \\
\hline$( \pm)$ S.D. & 0.01 & 0.0 & 0.0 & 0.0 & 0.0 & 0.03 & 0.02 & 0.03 & 0.03 & 0.02 \\
\hline Palampur G2 & 3.72 & 1.0 & 10.2 & 2.8 & 0.20 & 0.27 & 0.14 & 13.50 & 1.56 & 5.23 \\
\hline (士)S.D. & 0.02 & 0.02 & 0.02 & 0.01 & 0.01 & 0.01 & 0.01 & 0.01 & 0.02 & 0.02 \\
\hline Assam BOP & 3.92 & 0.8 & 8.1 & 5.6 & 0.35 & 0.42 & 0.45 & 8.57 & 2.30 & 8.53 \\
\hline$( \pm)$ S.D. & 0.04 & 0.02 & 0.02 & 0.01 & 0.01 & 0.02 & 0.01 & 0.01 & 0.01 & 0.01 \\
\hline Kurti & 3.54 & 0.6 & 6.8 & 6.4 & 0.39 & 0.43 & 0.82 & 13.80 & 4.82 & 14.04 \\
\hline ( \pm )S.D. & 0.02 & 0.01 & 0.01 & 0.02 & 0.01 & 0.01 & 0.02 & 0.01 & 0.02 & 0.05 \\
\hline
\end{tabular}

Values expressed are mean \pm S.D. of five experiments

Table 6: Season 3 (October-December) - Physicochemical analysis of black tea. 
Citation: Borse BB, Jagan Mohan Rao L (2012) Novel Bio-Chemical Profiling of Indian Black Teas with Reference to Quality Parameters. J Bioequiv Availab S14. doi:10.4172/jbb.S14-004

Page 11 of 16

The results for viscosity showed that it had a narrow range of variation during the third season, ie. 6.80 to $11.90 \mathrm{mPa}$. Tea brews from Parajulie (11.9 $\mathrm{mPa})$, Darjeeling premium $(11.8 \mathrm{mPa})$, Darjeeling Medium (11.6 mPa), Aibheel (11.5 mPa) and Nilgiri high grown (11.1 $\mathrm{mPa}$ ) had higher viscosities; whereas tea brews from Pandiar (10.4 $\mathrm{mPa})$, Assam Magor (10.30 mPa), Chinchula (10.3 mPa), Assam AFTL $(10.20 \mathrm{mPa})$ and Palampur $\mathrm{G}_{2}(10.2 \mathrm{mPa})$ had comparatively lower viscosities. Tea brews from Assam BOP $(8.1 \mathrm{mPa})$ and Kurti $(6.8 \mathrm{mPa})$ had lowest viscosities respectively.

Bulk densities (Loose and compacted or packed) of the tea samples from third season ranged from 0.20 to 0.45 and 0.27 to $0.49 \mathrm{~g} / \mathrm{ml}$ respectively. Aibheel and Chinchula teas can be marked by highest bulk densities (Loose and compacted) of 0.45 and $0.49 \mathrm{~g} / \mathrm{ml}$ and 0.42 and $0.46 \mathrm{~g} / \mathrm{ml}$ respectively, whereas Darjeeling Medium (0.25 and 0.32), Darjeeling premium ( 0.25 and 0.33$)$ and Nilgiri high grown $(0.25$ and $0.33)$ can be characterized by their lower bulk densities $(\mathrm{g} / \mathrm{ml}$, loose and compacted); Palampur $\mathrm{G}_{2}(0.20$ and 0.27$)$ can be characterized by the lowest bulk densities ( $\mathrm{g} / \mathrm{ml}$, loose and compacted). On the contrary Assam BOP (0.35 and 0.42), Kurti (0.39 and 0.43), Parajulie (0.38 and 0.42), Pandiar (0.38 and 0.42), Assam AFTL (0.39 and 0.45) and Assam Magor (0.37 and 0.42 ) teas had more or less similar and moderate bulk densities ( $\mathrm{g} / \mathrm{ml}$, loose and compacted).

The results of fingerprinting with respect to theaflavins, thearubigins, total colour and brightness for black tea samples from season-3 (Oct. - Dec.) are presented in Table 6 and figure 1.

It is evident from the results that theaflavin (TF) content varied from $0.14 \%$ (Palampur $\mathrm{G}_{2}$ ) to $1.86 \%$ (Assam Magor) and thearubigin (TR content) from $8.0 \%$ (Darjeeling premium) to $16.80 \%$ (Chinchula). Palampur $\mathrm{G}_{2}(0.14 \%$ and $13.50 \%)$, Assam BOP (0.45\% and $\left.8.57 \%\right)$, Darjeeling premium $(0.29 \%$ and $8.00 \%$ and Niligiri high grown $(0.54 \%$ and $8.42 \%)$ teas have the lowest TF and TR contents; whereas Darjeeling Medium (0.70\% and 9.15\%), Parajulie (0.74\% and $12.27 \%)$, Kurti $(0.82 \%$ and $13.80 \%)$ and Pandiar $(0.61 \%$ and $8.55 \%)$ had the marginally higher TF and TR content. Teas from Aibheel $(1.26 \%$ and $15.00 \%)$ and Chinchula (0.98\% and $16.80 \%)$ had further high TF and TR content; whereas the Assam teas, Assam AFTL (1.36\% and 16.29\%) and Assam Magor (1.86\% and 15.24\%) can be marked by their highest TF and TR content.

Almost similar trend is observed in the results for total colour and brightness. Assam Magor (6.56 and 26.97\%) and Assam AFTL (4.90 and $23.46 \%$ ) can be marked by highest colour and brightness followed by Aibheel (5.45 and 21.84), Chinchula (5.23 and 17.03\%) and Kurti (4.82 and 14.04\%). Teas from Palampur G2 (1.56 and 5.23\%) had lowest colour and brightness. Nilgiri high grown (1.38 and 18.58\%), Parajulie (2.76 and 16.18\%) and Pandiar (1.83 and 18.92\%) contained lower colour and moderate brightness. Assam BOP (2.30 and 8.53\%), Darjeeling Medium (2.04 and 9.05\%) and Darjeeling premium (2.06 and $11.85 \%$ ) have more or less moderate colour and brightness.

\begin{tabular}{|c|c|c|c|c|c|c|c|c|c|c|c|c|c|}
\hline $\begin{array}{l}\text { SI. } \\
\text { No. }\end{array}$ & Compound & $\begin{array}{l}\text { Para } \\
\text { julie }\end{array}$ & $\begin{array}{l}\text { Pan } \\
\text { diar }\end{array}$ & $\begin{array}{l}\text { Darjeelng } \\
\text { Medium }\end{array}$ & $\begin{array}{l}\text { Darjeel } \\
\text { Premim }\end{array}$ & $\begin{array}{c}\text { Assam } \\
\text { AFTL }\end{array}$ & $\begin{array}{l}\text { Assam } \\
\text { Magor }\end{array}$ & $\begin{array}{c}\text { Nilgiris } \\
\text { HG }\end{array}$ & $\begin{array}{l}\text { Aibh } \\
\text { eel }\end{array}$ & $\begin{array}{l}\text { Chin } \\
\text { chula }\end{array}$ & $\begin{array}{l}\text { Palam } \\
\text { pur G2 }\end{array}$ & Kurti* & $\begin{array}{c}\text { Assam } \\
\text { BOP }\end{array}$ \\
\hline 1 & n-hexanal & 362 & 1133 & 1227 & 1175 & A & 121 & 2817 & A & 216 & A & 31 & 168 \\
\hline 2 & Leaf aldehyde (E-2-hexenal) & 75 & 1617 & 1662 & 1225 & 703 & 1112 & 413 & 453 & 1341 & 2581 & 1349 & 1959 \\
\hline 3 & Leaf alcohol (Z-3-hexenol) & 1978 & 165 & 777 & 300 & A & 2 & 1710 & 90 & 1084 & 1890 & 97 & 12 \\
\hline 4 & trans / cis-2-hexenol & 233 & 91 & 176 & 110 & 267 & A & 382 & 95 & 33 & 244 & 102 & A \\
\hline 5 & n-hexenol & 68 & A & 205 & 830 & $\mathrm{~T}$ & $\mathrm{~T}$ & 321 & A & 22 & 503 & A & 43 \\
\hline 6 & n-heptanal & 70 & 94 & 633 & $\mathrm{~T}$ & 139 & 92 & 52 & 56 & $\mathrm{~T}$ & 234 & A & A \\
\hline 7 & Benzaldehyde & 66 & 49 & 72 & 145 & 167 & 131 & 78 & 63 & 57 & 165 & 39 & 38 \\
\hline 8 & $(\mathrm{E}, \mathrm{Z})-2,4-$ Heptadienal & A & A & A & A & A & A & A & $\mathrm{T}$ & 130 & 323 & $\mathrm{~T}$ & A \\
\hline 9 & $(\mathrm{E}, \mathrm{E})-2,4-$ Heptadienal & A & A & A & A & A & A & $\mathrm{T}$ & 74 & 178 & 381 & 11 & $\mathrm{~T}$ \\
\hline 10 & Nonanal & A & 32 & 54 & $\mathrm{~T}$ & 114 & 123 & A & 119 & 163 & 129 & A & A \\
\hline 11 & Phenyl acetaldehyde & 1285 & 766 & 464 & 715 & 1106 & 646 & 329 & 696 & 506 & 133 & 1072 & 378 \\
\hline 12 & Benzyl alcohol & 197 & 782 & 158 & 205 & 539 & 379 & $\mathrm{~T}$ & 453 & 367 & 754 & $\mathrm{~T}$ & 24 \\
\hline 13 & cis-linalool oxide & 120 & 198 & 4705 & 5755 & 1194 & 821 & 1565 & 290 & 400 & 503 & 34 & 24 \\
\hline 14 & trans-linalool oxide & 360 & 0 & 0 & 0 & 0 & 0 & 0 & 822 & 0 & 1287 & 105 & 55 \\
\hline 15 & Linalool & 93 & 727 & 906 & 3201 & 1106 & 900 & 2071 & 1052 & 635 & 851 & 45 & 13 \\
\hline 16 & Phynyl ethyl alcohol & A & 0 & 295 & 1350 & A & 0 & A & 0 & 152 & 511 & 200 & 133 \\
\hline 17 & a-terpineol & A & A & 2072 & $\mathrm{~T}$ & 203 & A & A & A & A & 285 & 10 & 41 \\
\hline 18 & Methyl salicylate & 457 & 374 & 658 & 2885 & 1241 & 500 & 592 & 1225 & 295 & 1257 & 95 & 34 \\
\hline 19 & cis-Geraniol & 292 & 409 & 3658 & 3925 & 128 & 177 & 714 & 138 & 316 & 657 & 15 & 9 \\
\hline 20 & Geranyl acetate & 118 & 101 & 201 & A & 164 & 198 & A & 81 & 120 & 201 & A & 9 \\
\hline 21 & $\beta$-lonone & 188 & 188 & 176 & 230 & 103 & 77 & $\mathrm{~T}$ & 162 & A & 105 & 33 & 18 \\
\hline 22 & Nerolidol & A & A & 396 & 560 & A & A & 136 & A & A & 245 & 26 & 19 \\
\hline 23 & Phytol & 3009 & 5075 & A & A & 1361 & 1102 & 796 & 3928 & 1177 & A & 1308 & 493 \\
\hline 24 & Indole & A & A & A & A & A & A & A & A & A & $\mathrm{T}$ & 10 & 23 \\
\hline \multirow[t]{5}{*}{25} & dihydroactinidiolide & A & A & A & A & A & A & A & A & A & A & 24 & 26 \\
\hline & Total & 5962 & 6726 & 18495 & 22611 & 7174 & 5279 & 11180 & 5869 & 6015 & 13239 & 3298 & 3026 \\
\hline & Terpene Index & 0.66 & 0.69 & 0.60 & 0.69 & 0.95 & 0.90 & 0.83 & 0.94 & 0.76 & 0.80 & 0.92 & 0.91 \\
\hline & Yamanishi Botheju ratio & 1.24 & 0.45 & 0.54 & 2.61 & 1.57 & 0.80 & 5.01 & 2.32 & 0.47 & 0.33 & 0.03 & 0.07 \\
\hline & Mahanta ratio & 0.41 & 0.51 & 2.52 & 3.61 & 2.08 & 1.37 & 0.78 & 2.68 & 0.46 & 0.64 & 0.18 & 0.10 \\
\hline
\end{tabular}

* Phytol is not included in the total volatiles as well as in mahanta ratio (refer results and discussion for details)

@ Values expressed are mean of three experiments, Where $A=$ absent, $T=$ trace

Table 7: Season 3 (October - December)- Black tea samples-volatile flavour compounds (VFC) $\mu \mathrm{g} / 100 \mathrm{~g}^{\circledR}$. 
Citation: Borse BB, Jagan Mohan Rao L (2012) Novel Bio-Chemical Profiling of Indian Black Teas with Reference to Quality Parameters. J Bioequiv Availab S14. doi:10.4172/jbb.S14-004

Page 12 of 16

The results of the fingerprinting with respect to volatile flavour compounds for season-3 (Oct. - Dec.) are presented in Table 7 and figure 3. It is clear from the results that

1.The total quantity of volatiles is in the range of $3.30-22.61$ $\mathrm{mg} / 100 \mathrm{~g}$ of tea sample during this season. Darjeeling premium and medium possess highest quantity (22.61 and $18.50 \mathrm{mg} \%$ respectively) of total volatiles, where as Kurti has lowest (3.30 mg $\%)$. Palampur G2, Nilgiri high grown, Assam AFTL, Pandiar and Chinchula contained higher amounts of total volatiles. Content of phytol is not considered for total volatiles, as it is a product derived from chlorophylls during degradation.

2.Marker for Parajulie is lowest leaf aldehyde content (65 - 85 $\mu \mathrm{g} / 100 \mathrm{~g})$

3.Marker for Pandiar is lower leaf alcohol content (150 - 180 $\mu \mathrm{g} / 100 \mathrm{~g})$ and lowest $(40-60 \mu \mathrm{g} / 100 \mathrm{~g})$ benzaldehyde content.

4.Marker for Darjeeling premium is highest linalool content (3201 $\mu \mathrm{g} / 100 \mathrm{~g})$ and methyl salicylate $(2870-2900 \mu \mathrm{g} / 100 \mathrm{~g})$ content.

5.Marker for Darjeeling Medium is highest a-terpineol content $(2050-2090 \mu \mathrm{g} / 100 \mathrm{~g})$ and $\mathrm{n}$-heptanal $(620-650 \mu \mathrm{g} / 100 \mathrm{~g})$ content

6.Marker for Nilgiris high grown is highest $\mathrm{n}$-hexanal (2800-2830 $\mu \mathrm{g} / 100 \mathrm{~g})$ content.

7.Marker for Assam AFTL and Assam magor is the lowest leaf alcohol $(0-20 \mu \mathrm{g} / 100 \mathrm{~g})$ content.

8.Marker for Aibheel is the lower content of geranyl acetate (70 - 90 $\mu \mathrm{g} / 100 \mathrm{~g})$
9.Marker for Chinchula is the lowest $(10-30 \mu \mathrm{g} / 100 \mathrm{~g})$ content of $\mathrm{n}$ - hexenol.

10.Special marker for Kurti is the presence of Xylene (1375-1425 $\mu \mathrm{g} / 100 \mathrm{~g})$.

11.Markers for Assam BOP are the lowest content of geraniol (0-20 $\mu \mathrm{g} / 100 \mathrm{~g})$ and geranyl acetate $(0-20 \mu \mathrm{g} / 100 \mathrm{~g})$ content.

Terpene index, Yamanishi-Botheju ratio and Mahanta ratio for the volatile flavour compounds are calculated and presented in table 7. The terpene index of Aibheel, Assam AFTL, Kurti, Assam BOP and Assam Magor is approaching unity $(0.90-0.95)$ and indicating these to be hybrids dominated by assamica. Nilgiris high grown, Palampur G2, Chinchula, Darjeeling premium, Pandiar, Parajulie and Darjeeling Medium teas are found to be hybrids of assamica and sinensis, from their terpene indices $(0.83,0.80,0.76,0.69,0.69,0.66$ and 0.60 respectively).

Darjeeling premium, Aibheel, Darjeeling medium and Assam AFTL teas showed highest Mahanta ratios $(3.61$ - 2.09) for VFCs indicating the presence of more quantities of desirable VFC, which indicate better quality of flavour during the third season. Assam Magor, Nilgiris high grown, Palampur G2 and Pandiar teas showed medium Mahanta ratios (1.37 - 0.56) and are moderate quality with regard to flavour during this season. Chinchula, Parajulie, Kurti and Assam BOP possess lowest mahanta ratio and indicating flavour is low. Yamanishi-Botheju ratios of these teas also support the above findings.

Profiling of the tea samples from fourth season (JanuaryMarch)

The results of the physico-chemical analyses for Black Tea Samples

\begin{tabular}{|c|c|c|c|c|c|c|c|c|c|c|}
\hline \multirow{2}{*}{ Sample } & \multirow{2}{*}{$\begin{array}{c}\text { Soluble } \\
\text { Caffeine (\%) }\end{array}$} & \multirow{2}{*}{ TSS (\%) } & \multirow{2}{*}{$\begin{array}{c}\text { Viscosity } \\
\text { (mPa) }\end{array}$} & \multirow{2}{*}{ Moisture (\%) } & \multicolumn{2}{|c|}{ Bulk density $(\mathrm{g} / \mathrm{ml})$} & \multirow{2}{*}{$\begin{array}{l}\mathrm{TF} \\
(\%)\end{array}$} & \multirow{2}{*}{$\begin{array}{l}\text { TR } \\
(\%)\end{array}$} & \multirow{2}{*}{$\begin{array}{l}\text { Total } \\
\text { colour }\end{array}$} & \multirow{2}{*}{$\begin{array}{c}\text { Brightness } \\
(\%)\end{array}$} \\
\hline & & & & & Loose & Packed & & & & \\
\hline Parajulie & 4.16 & 0.15 & 12.3 & 5.13 & 0.38 & 0.43 & 0.83 & 10.20 & 2.48 & 15.43 \\
\hline S.D. $( \pm)$ & 0.02 & 0.00 & 0.00 & 0.02 & 0.01 & 0.01 & 0.02 & 0.04 & 0.06 & 0.05 \\
\hline Pandiar & 3.28 & 0.15 & 10.60 & 4.73 & 0.39 & 0.43 & 0.64 & 7.80 & 1.91 & 17.36 \\
\hline S.D. $( \pm)$ & 0.01 & 0.00 & 0.00 & 0.01 & 0.02 & 0.02 & 0.03 & 0.05 & 0.05 & 0.04 \\
\hline Assam AFTL & 4.67 & 0.15 & 10.3 & 6.93 & 0.39 & 0.43 & 1.39 & 16.26 & 4.55 & 22.81 \\
\hline S.D.( $( \pm)$ & 0.02 & 0.00 & 0.06 & 0.03 & 0.01 & 0.01 & 0.02 & 0.06 & 0.04 & 0.06 \\
\hline Assam Magor & 5.28 & 0.15 & 10.10 & 4.67 & 0.40 & 0.44 & 1.77 & 14.25 & 6.35 & 27.94 \\
\hline S.D. $( \pm)$ & 0.02 & 0.00 & 0.00 & 0.02 & 0.01 & 0.01 & 0.04 & 0.03 & 0.03 & 0.03 \\
\hline Darj. Medium & 3.21 & 0.15 & 11.60 & 7.07 & 0.24 & 0.30 & 0.61 & 9.20 & 2.33 & 10.11 \\
\hline \pm S.D. & 0.01 & 0.00 & 0.00 & 0.02 & 0.00 & 0.01 & 0.03 & 0.02 & 0.01 & 0.01 \\
\hline Darj. Premium & 4.50 & 0.25 & 12.00 & 6.40 & 0.25 & 0.32 & 0.39 & 9.28 & 2.18 & 10.87 \\
\hline (士)S.D. & 0.02 & 0.00 & 0.00 & 0.00 & 0.01 & 0.00 & 0.02 & 0.02 & 0.01 & 0.02 \\
\hline Nil-HG & 3.67 & 0.15 & 11.4 & 4.8 & 0.33 & 0.38 & 0.65 & 8.94 & 1.77 & 15.90 \\
\hline S.D. $( \pm)$ & 0.01 & 0.00 & 0.00 & 0.01 & 0.01 & 0.00 & 0.03 & 0.03 & 0.03 & 0.05 \\
\hline Aibheel & 3.88 & 0.25 & 11.00 & 4.80 & 0.44 & 0.48 & 1.50 & 16.56 & 6.16 & 21.78 \\
\hline$( \pm)$ S.D. & 0.01 & 0.00 & 0.00 & 0.00 & 0.01 & 0.01 & 0.04 & 0.04 & 0.02 & 0.01 \\
\hline Chinchula & 5.23 & 0.25 & 10.60 & 5.20 & 0.41 & 0.45 & 0.88 & 15.78 & 4.10 & 15.45 \\
\hline$( \pm)$ S.D. & 0.02 & 0.00 & 0.00 & 0.00 & 0.00 & 0.01 & 0.03 & 0.05 & 0.02 & 0.01 \\
\hline Assam OP & 2.84 & 0.6 & 5.6 & 5.8 & 0.24 & 0.31 & 0.27 & 14.56 & 3.94 & 2.52 \\
\hline$( \pm)$ S.D. & 0.02 & 0.01 & 0.02 & 0.02 & 0.03 & 0.01 & 0.01 & 0.03 & 0.01 & 0.01 \\
\hline Nil.Wynad CTC-BOP & 2.03 & 0.4 & 6.2 & 6.0 & 0.41 & 0.47 & 0.75 & 12.69 & 3.60 & 16.61 \\
\hline ( \pm S.D. & 0.01 & 0.01 & 0.01 & 0.03 & 0.02 & 0.01 & 0.03 & 0.01 & 0.01 & 0.03 \\
\hline Annamalai & 2.78 & 0.4 & 4.8 & 4.6 & 0.43 & 0.49 & 0.64 & 11.83 & 3.49 & 10.24 \\
\hline$( \pm)$ S.D. & 0.01 & 0.01 & 0.02 & 0.01 & 0.01 & 0.02 & 0.01 & 0.01 & 0.02 & 0.02 \\
\hline
\end{tabular}

* Special marker-Xylene is present upto $1400 \mu \mathrm{g} / 100 \mathrm{~g}$ tea

Values expressed are mean \pm S.D. of five

Table 8: Season 4 (January-March) - Physicochemical analysis of black tea 
from season-4 (January-March) are presented in Table 8. It is clear from the results that the moisture content of teas varied from $4.6 \%$ to $7.1 \%$ and soluble caffeine content of the tea samples from fourth season ranged from $2.03 \%$ to $5.28 \%$. Assam Magor (5.28\%) had highest soluble caffeine content followed by Chinchula (5.23\%) and Assam AFTL (4.67\%). Darjeeling Premium, Parajulie, Aibheel and Nilgiri high grown have comparatively moderate quantity (in the range of $3.60-4.50 \%)$ of soluble caffeine content; whereas Pandiar (3.28\%) and Darjeeling Medium (3.21\%) have still lower soluble caffeine content. Assam OP, Nilgiris Waynad CTC-BOP and Annamalai teas had lowest soluble caffeine content (2.03-2.84\%).

Tea brews of Assam OP, Nilgiris Waynad CTC-BOP and Annamalai teas had the highest total soluble solids content (0.4-0.6\%) compared to Darjeeling Premium, Aibheel and Chinchula which have the higher total soluble solids $(0.25 \%)$ content; whereas tea brews from Parajulie, Pandiar, Assam AFTL, Assam Magor, Darjeeling Medium and Nilgiri high grown have the lowest total soluble solids $(0.15 \%)$ content.

The results for viscosity of tea brews ranged between 4.8 and 12.3 $\mathrm{mPa}$. Parajulie (12.30 mPa) and Darjeeling Premium (12.0 mPa) had highest viscosities. Darjeeling Medium (11.60 mPa), Nilgiri high grown $(11.40 \mathrm{mPa})$ and Aibheel $(11 \mathrm{mPa})$, have higher viscosities. Pandiar, Chinchula, Assam AFTL and Assam Magor had moderate viscosity in the range of 10.60-10.00 $\mathrm{mPa}$. Assam OP, Nilgiris Waynad CTC-BOP and Annamalai teas had the lowest (4.80 -6.20 $\mathrm{mPa}$ ) viscosities.

Darjeeling Medium $(0.24$ and $0.30 \mathrm{~g} / \mathrm{ml})$, Darjeeling Premium $(0.25$ and $0.32 \mathrm{~g} / \mathrm{ml})$, Assam OP $(0.24$ and $0.31 \mathrm{~g} / \mathrm{ml})$ and Nilgiri high grown (0.33 and 0.38) have the lowest bulk densities (Loose and packed). Aibheel (0.44 and $0.48 \mathrm{~g} / \mathrm{ml})$, Chinchula ( 0.41 and $0.45 \mathrm{~g} / \mathrm{ml})$, Nilgiris Waynad CTC-BOP $(0.41$ and $0.47 \mathrm{~g} / \mathrm{ml})$ and Annamalai teas $(0.43$ and $0.49 \mathrm{~g} / \mathrm{ml}$ ) had the highest bulk densities (Loose and compacted). On the contrary Assam AFTL (0.39 and $0.43 \mathrm{~g} / \mathrm{ml})$, Assam Magor $(0.40$ and $0.44 \mathrm{~g} / \mathrm{ml})$, Pandiar $(0.39$ and $0.43 \mathrm{~g} / \mathrm{ml})$ and Parajulie $(0.38$ and $0.43 \mathrm{~g} / \mathrm{ml}$ ) had more or less same and moderate bulk densities (loose and packed).

The results of fingerprinting of theaflavins, thearubigins, total colour and brightness for black tea samples from season-4 (JanuaryMarch) are presented in Table 8 and figure 2.

It is clear from the results that the TF and TR contents of the tea samples from fourth season (January-March) ranged between 0.27$1.77 \%$ and $7.80-16.56 \%$ respectively. Assam Magor (1.77 and $14.25 \%)$, Assam AFTL (1.39 and 16.26\%) and Aibheel (1.50 and 16.56\%) teas can be marked by highest TF and TR contents. Nilgiris Waynad CTC-BOP, Parajulie and Chinchula have comparatively moderate quantities for TF $(0.75,0.83$ and $0.88 \%)$ and TR $(12.69,10.20$ and $15.78 \%)$ respectively. Darjeeling Premium, Darjeeling Medium, Annamalai and Nilgiri high grown, can be marked by lower values of TF $(0.39,0.61,0.64,0.65 \%)$ and TR $(9.28,9.20,11.83,8.94, \%)$ respectively. Assam OP tea had the lowest TF $(0.27 \%)$ of all teas and moderate content of TR (14.56\%). Pandiar tea had the lowest TR $(7.80 \%)$ of all teas and moderate content of TF $(0.64 \%)$.

Total colour varied in the range of 1.77-6.35 and brightness varied in the 2.52-27.94\%. Not only for TF and TR but also for total colour and brightness the three teas viz., Assam Magor - 6.35 and 27.94\%; Assam AFTL - 4.55 and 22.81\%; and Aibheel 6.16 and 21.78\% showed the presence of higher values. Assam OP had showed the lowest brightness $(2.52 \%)$ and moderate colour (3.94), where as Nilgiri high grown and Pandiar showed lowest colour (1.77 and 1.91 respectively) and moderate brightness (15.90 and $17.36 \%$ respectively). Parajulie, Nilgiris Waynad CTC-BOP and Chinchula have comparatively moderate values for total colour $(2.48,3.60$ and 4.10$)$ and brightness $(15.43,16.61$ and $15.45 \%$ ) respectively. Although, Annamalai teas has moderate total colour (3.49) the brightness (10.24 \%) is lower. Darjeeling Medium and Darjeeling Premium can be marked by comparatively lower values of total colour (2.33 and 2.18) and brightness (10.11 and $10.87 \%$ ) respectively.

The results of the fingerprinting with respect to volatile flavour compounds for black tea samples from season-4 (January-March) are presented in Table 9 and figure 3. It is clear from the results obtained for fingerprinting of volatile flavour compounds that

1.The total of volatiles is in the range of $1.8-61.49 \mathrm{mg} / 100 \mathrm{~g}$ of tea sample during this season. Nilgiri high grown possesses highest quantity (61.49 $\mathrm{mg} \%)$ of total volatiles, where as Assam OP has lowest $(1.8 \mathrm{mg} \%)$.

Darjeeling Medium and Premium, Parajulie and Pandiar teas contained higher amounts of total volatiles. Content of phytol is not considered for total volatiles, as it is product derived from chlorophylls during degradation.

2.Marker for pandiar is highest $(1700-1720 \mu \mathrm{g} / 100 \mathrm{~g})$ content of n-hexanal.

3.Marker for Darjeeling medium is highest $(3800-3900 \mu \mathrm{g} / 100 \mathrm{~g})$ content of linalool.

4.Marker for Annamalai is lowest $(30-50 \mu \mathrm{g} / 100 \mathrm{gm})$ content of $\mathrm{n}$ - hexanal and leaf alcohol (18 $\mu \mathrm{g} / 100 \mathrm{gm})$.

5.Marker for Assam AFTL is lower $(200 \mu \mathrm{g} / 100 \mathrm{~g})$ content of leaf alcohol.

6.Marker for Assam magor is the highest $(11840-11880 \mu \mathrm{g} / 100 \mathrm{~g})$ content of phytol.

7.Marker for Nilgiris highgrown is the highest content of leaf aldehyde (17480 - $17520 \mu \mathrm{g} / 100 \mathrm{~g})$, phenyl acetaldehyde (2850 $-2890 \mu \mathrm{g} / 100 \mathrm{~g})$ and the phenyl ethyl alcohol $(7410-7450$ $\mu \mathrm{g} / 100 \mathrm{~g})$.

8.Markers for Aibheel are the lowest contents of trans/cis -2-hexenol (10 - 30 $\mu \mathrm{g} / 100 \mathrm{~g}), \mathrm{n}$ - heptanal (15- $35 \mu \mathrm{g} / 100 \mathrm{~g})$ and nonanal $(25-65 \mu \mathrm{g} / 100 \mathrm{~g})$

9.Marker for chinchula is the lowest $(245-285 \mu \mathrm{g} / 100 \mathrm{~g})$ content of leaf aldehyde.

Novel approach for overall quality based on seasonal, regional, grade variations and bio-chemical quality fingerprint is developed. The codes are given for each region/garden/location for convenience (Figure 1).

\section{Seasonal variation of TF/TR ratio over tea producing region/ grade and quality}

The TF content of a tea or the ratio TF/TR is considered to be a good quality indicator of tea. Accordingly Figure 4 presents seasonal variations of $\mathrm{TF} / \mathrm{TR}$ ratios over the coded tea producing regions/ grades in all the four seasons $\left(\mathrm{s}_{1}, \mathrm{~s}_{2}, \mathrm{~s}_{3} \mathrm{~s}_{4}\right)$. Teas having TF/TR ratios upto $0.04,>0.04-0.08$ and $>0.08$ can be considered to be good, better and best quality indicator of tea quality respectively. Teas from the region/ grade A-I are the better (TF/TR ratios $>0.04-0.08)$ to best $(\mathrm{TF} / \mathrm{TR}$ ratios 
Citation: Borse BB, Jagan Mohan Rao L (2012) Novel Bio-Chemical Profiling of Indian Black Teas with Reference to Quality Parameters. J Bioequiv Availab S14. doi:10.4172/jbb.S14-004

Page 14 of 16

\begin{tabular}{|c|c|c|c|c|c|c|c|c|c|c|c|c|c|}
\hline $\begin{array}{l}\text { Sl. } \\
\text { No. }\end{array}$ & Compound & $\begin{array}{l}\text { Para } \\
\text { julie }\end{array}$ & $\begin{array}{l}\text { Pan } \\
\text { diar }\end{array}$ & $\begin{array}{c}\text { Darjeel } \\
\text { Medium }\end{array}$ & $\begin{array}{c}\text { Darjeel } \\
\text { Premium }\end{array}$ & $\begin{array}{c}\text { Assam } \\
\text { AFTL }\end{array}$ & $\begin{array}{l}\text { Assam } \\
\text { Magor }\end{array}$ & $\begin{array}{c}\text { Nilgiri } \\
\text { HG }\end{array}$ & $\begin{array}{l}\text { Aibh } \\
\text { eel }\end{array}$ & $\begin{array}{l}\text { Chin } \\
\text { chula }\end{array}$ & $\begin{array}{c}\text { Assam } \\
\text { OP }\end{array}$ & Anamalai & $\begin{array}{l}\text { Nilgiris } \\
\text { Waynad }\end{array}$ \\
\hline 1 & n-hexanal & 1259 & 1707 & A & 507 & A & A & 1333 & 1066 & 1399 & $T$ & 35 & A \\
\hline 2 & Leaf aldehyde (E2-hexenal) & 2108 & 2457 & 1197 & 1467 & 1435 & 1026 & 17500 & 533 & 265 & 434 & 889 & 1581 \\
\hline 3 & Leaf alcohol (Z-3-hexenol) & 238 & 344 & 1094 & 667 & 200 & 90 & 1893 & 81 & 146 & 94 & 18 & 51 \\
\hline 4 & Transicis-2-hexenol & 62 & $\mathrm{~T}$ & 175 & 180 & 96 & A & 5190 & 21 & 253 & A & A & A \\
\hline 5 & n-hexenol & A & 165 & 491 & A & A & A & 1440 & $T$ & A & A & 15 & 79 \\
\hline 6 & n-heptanal & 96 & 125 & 111 & 153 & 300 & 276 & 2357 & 25 & 280 & A & 55 & A \\
\hline 7 & Benzaldehyde & 117 & $\mathrm{~T}$ & 20 & 300 & 127 & 82 & 440 & 131 & 122 & 104 & 35 & 62 \\
\hline 8 & (E,Z)-2,4-Heptadienal & A & A & A & A & A & A & A & A & A & A & 5 & 8 \\
\hline 9 & $(\mathrm{E}, \mathrm{E})-2,4-$ Heptadienal & 151 & 122 & 149 & 333 & 119 & A & 428 & 72 & A & 7 & 9 & 14 \\
\hline 10 & Nonanal & 117 & $\mathrm{~T}$ & 308 & 313 & 211 & 194 & 452 & 45 & A & A & A & A \\
\hline 11 & Phenyl acetaldehyde & 1352 & 793 & 1440 & 1780 & 1327 & 750 & 2869 & 908 & 908 & 382 & 355 & 350 \\
\hline 12 & Benzyl alcohol & 605 & 518 & 684 & 167 & A & A & 2107 & 221 & 299 & 37 & 31 & $T$ \\
\hline 13 & Cis-linalool oxide & 654 & 558 & 2624 & 2827 & 1108 & 534 & 9917 & 468 & 582 & 31 & 28 & 22 \\
\hline 14 & Trans-linalool oxide & & & 5141 & 5393 & & & & & & 79 & 89 & 89 \\
\hline 15 & Linalool & 1513 & 1357 & 3850 & 1873 & 1138 & 655 & A & 762 & 875 & 19 & 256 & 438 \\
\hline 16 & Phynyl ethyl alcohol & & A & 1513 & & A & A & 7429 & A & A & 365 & 256 & 408 \\
\hline 17 & Alfa-terpineol & A & A & A & A & A & A & 3702 & A & A & 36 & 26 & 36 \\
\hline 18 & Methyl salicylate & 413 & 457 & 1739 & 2273 & 373 & 202 & 1238 & 216 & 329 & 36 & 25 & 41 \\
\hline 19 & Cis-Geraniol & 639 & 698 & 4158 & 3120 & A & A & 1667 & 131 & A & 18 & 74 & 149 \\
\hline 20 & Geranyl acetate & 346 & 113 & 145 & A & 177 & A & A & 21 & A & 19 & 8 & 7 \\
\hline 21 & $\beta$-lonone & 417 & 271 & 222 & 380 & 181 & 276 & 1524 & 138 & 134 & 33 & 52 & 44 \\
\hline 22 & Nerolidol & A & A & A & A & A & A & A & A & A & 27 & 19 & 29 \\
\hline 23 & Phytol & 799 & 5628 & 3205 & 3407 & 7285 & 11858 & A & 3101 & 8598 & A & 443 & 888 \\
\hline 24 & Indole & A & A & A & A & A & A & A & A & A & 23 & 10 & 11 \\
\hline 25 & Dihydroactinidiolide & A & A & A & A & A & A & A & A & A & 68 & 22 & 43 \\
\hline & Total & 10087 & 9685 & 25061 & 21733 & 6792 & 4085 & 61486 & 4839 & 5592 & 1805 & 2312 & 3462 \\
\hline & Terpene Index & 0.77 & 0.73 & 0.73 & 0.76 & 1.0 & 1.0 & 0.85 & 0.90 & 1.0 & 0.88 & 0.83 & 0.79 \\
\hline & Yamanishi Botheju ratio & 0.72 & 0.55 & 3.22 & 1.28 & 0.79 & 0.64 & - & 1.43 & 3.30 & 0.04 & 0.29 & 0.27 \\
\hline & Mahanta ratio & 0.86 & 0.61 & 4.55 & 3.47 & 1.05 & 0.88 & 0.54 & 0.77 & 0.65 & 0.52 & 0.54 & 0.48 \\
\hline
\end{tabular}

* Phytol is not included in the total volatiles as well as in mahanta ratio (refer results and discussion for details)

@ Values expressed are mean of three experiments, Where $\mathrm{A}=$ absent, $\mathrm{T}=$ trace

Table 9: Season 4 (January - March)- Black tea samples-volatile flavour compounds (VFC) $\mu$ g / $100 \mathrm{~g}^{\circledR}$

$>0.08$ ) quality teas over all the four seasons except for the teas from region $\mathrm{A}, \mathrm{C}, \mathrm{D}\left(\mathrm{s}_{1}\right)$, which fall under good quality category considering their $\mathrm{TF} / \mathrm{TR}$ ratios (upto 0.04 ).

Also the teas from region/grade K-L $\left(\mathrm{s}_{2}\right)$, region $\mathrm{N}, \mathrm{O}\left(\mathrm{s}_{1}\right)$, region PQ $\left(\mathrm{s}_{3}\right)$ and region RS $\left(\mathrm{s}_{4}\right)$ are the better (TF/TR ratios >0.04-0.08) quality teas except for the teas from region $\mathrm{J}\left(\mathrm{s}_{2}\right), \mathrm{M}\left(\mathrm{s}_{3}\right)$ and $\mathrm{T}\left(\mathrm{s}_{4}\right)$ teas, which fall under good quality category considering their TF/TR ratios (upto 0.04).

The teas from region/grade JKL $\left(\mathrm{s}_{1} \mathrm{~s}_{3}\right), \mathrm{M}-\mathrm{T}\left(\mathrm{s}_{2}\right)$, ORST $\left(\mathrm{s}_{3}\right)$, MP $\left(\mathrm{s}_{1}\right), \mathrm{Q}\left(\mathrm{s}_{4}\right)$ are also falling under good quality category teas, considering their TF/TR ratios (upto 0.04).

\section{Seasonal variation of sum of Yamanishi-Botheju and Mahanta ratio over tea producing region/grade and tea quality}

The VFC content of a tea or the sum of the VFC ratios (YamanishiBotheju ratio and Mahanta ratio) is considered to be a good quality indicator of tea. Accordingly Figure 5 presents seasonal variations of or the sum of the VFC ratios (Yamanishi-Botheju ratio and Mahanta ratio) over the coded tea producing regions/grades in all the four seasons $\left(\mathrm{s}_{1}, \mathrm{~s}_{2}, \mathrm{~s}_{3}, \mathrm{~s}_{4}\right)$. Accordngly based on the sum of the VFC ratios (i.e.Yamanishi-Botheju ratio and Mahanta ratio) the teas can be categorized as a good (upto 1 ), better ( $>1-4$ ) and best (>4) quality indicator of tea respectively.

The teas from regions/grade A-J (all seasons) have better (>1-4) to best $(>4)$ quality as indicated by sum of the VFC ratios (i.e.YamanishiBotheju ratio and Mahanta ratio) except for teas from regions/grade $\operatorname{AEFHIJ}\left(s_{2}\right), \mathrm{K}-\mathrm{T}\left(\mathrm{s}_{2}\right), \operatorname{BDFHIJ}\left(\mathrm{s}_{1}\right), \operatorname{BIJ}\left(\mathrm{s}_{3}\right)$ which are good (upto 1) quality teas, as indicated by sum of the two VFC ratios. Also the teas from regions/grade $\mathrm{M}\left(\mathrm{s}_{3}\right), \mathrm{O}\left(\mathrm{s}_{1}\right), \mathrm{P}\left(\mathrm{s}_{3}\right)$, RST $\left(\mathrm{s}_{4}\right)$ are good (upto 1) quality teas as indicated by sum of the two VFC ratios.

\section{Seasonal variation of Borse-Rao quality index over tea producing region/grade and tea quality}

The sum of TF/TR ratios of tea and the sum of the VFC ratios (Yamanishi-Botheju ratio and Mahanta ratio) added together is

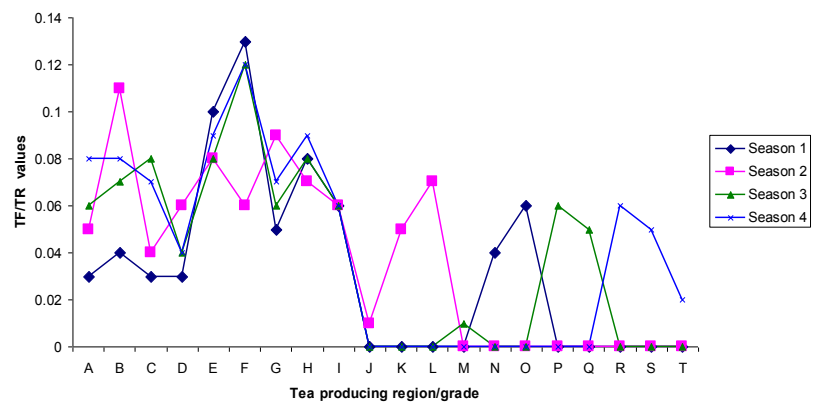

Figure 4: Seasonal variation of TF/TR ratio over tea producing region/grade. 
Citation: Borse BB, Jagan Mohan Rao L (2012) Novel Bio-Chemical Profiling of Indian Black Teas with Reference to Quality Parameters. J Bioequiv Availab S14. doi:10.4172/jbb.S14-004

Page 15 of 16

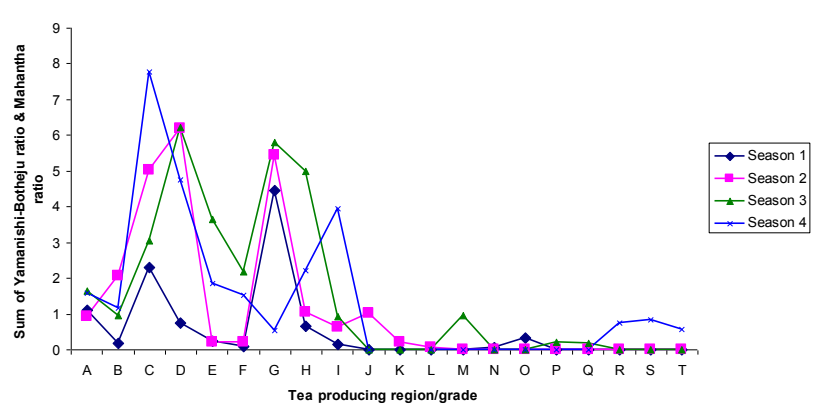

Figure 5: Seasonal variation of sum of Yamanishi-Botheju and Mahantha ratio over tea producing region/grade.

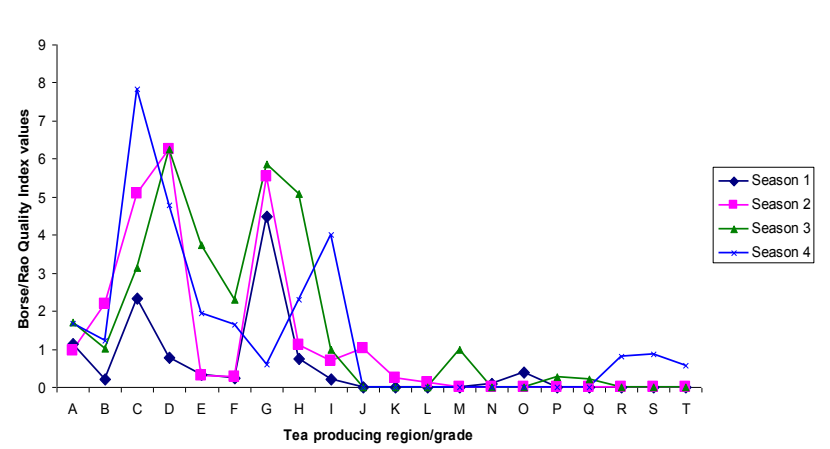

Figure 6: Seasonal variation of Borse-Rao quality index over tea producing region/grade.

proposed for the first time as a new and novel quality index, hence forth referred to as Borse-Rao quality index, considered to be an overall quality indicator of tea as both the non-volatiles/volatiles are given due consideration in this quality index. Accordingly Figure 6 presents seasonal variations of the Borse-Rao quality index over the coded tea producing regions/grades in all the four seasons $\left(\mathrm{s}_{1} \mathrm{~s}_{2}, \mathrm{~s}_{3}, \mathrm{~s}_{4}\right)$. Accordingly based on the the Borse-Rao quality index teas can be categorized as good (upto 1), better (>1-4) and best (>4) quality tea respectively.

The teas from regions/grade having Borse-Rao quality index more than four are $\mathrm{C}\left(\mathrm{s}_{2}, \mathrm{~s}_{4}\right), \mathrm{D}\left(\mathrm{s}_{3}, \mathrm{~s}_{4}\right), \mathrm{G}\left(\mathrm{s}_{1}, \mathrm{~s}_{2}, \mathrm{~s}_{3}\right), \mathrm{H}\left(\mathrm{s}_{3}\right)$ and $\mathrm{I}\left(\mathrm{s}_{4}\right)$ are the best (>4) quality teas.

The teas from regions/grade having Borse-Rao quality index ranging from one to four are $\mathrm{A}\left(\mathrm{s}_{1} \mathrm{~s}_{2} \mathrm{~s}_{3} \mathrm{~s}_{4}\right), \mathrm{B}\left(\mathrm{s}_{2} \mathrm{~s}_{3} \mathrm{~s}_{4}\right), \mathrm{C}\left(\mathrm{s}_{1} \mathrm{~s}_{3}\right), \mathrm{E}\left(\mathrm{s}_{3}, \mathrm{~s}_{4}\right)$, $\mathrm{F}\left(\mathrm{s}_{3} \mathrm{~s}_{4}\right), \mathrm{H}\left(\mathrm{s}_{2} \mathrm{~s}_{4}\right), \mathrm{I}\left(\mathrm{s}_{3} \mathrm{~s}_{4}\right), \mathrm{J}\left(\mathrm{s}_{2}\right), \mathrm{M}\left(\mathrm{s}_{3}\right)$ and $\mathrm{RS}\left(\mathrm{s}_{4}\right)$ and indicate that these are better (>1-4) quality teas.

The rest of the teas from regions/grade having Borse-Rao quality index upto one are good quality teas which are BDFH $\left(\mathrm{s}_{1}\right), \mathrm{EF}\left(\mathrm{s}_{2}\right), \mathrm{I}$ $\left(\mathrm{s}_{1}, \mathrm{~s}_{2}\right)$, JKL $\left(\mathrm{s}_{3}\right)$, K-T $\left(\mathrm{s}_{2}\right)$ and P-T $\left(\mathrm{s}_{3}\right)$.

\section{Acknowledgment}

We thank the Director, CFTRI, Mysore, and Head of the Department of Plantation Products, Spices and Flavour Technology, CFTRI, Mysore, for their support and the facilities provided.

\section{References}

1. Ramadurai N (2000) Global trade trends in tea. Planters Chronicle. December 2000, 537.

2. Takeo T, Mahanta PK (1983) Comparison of black tea aromas of orthodox and CTC tea and of black tea made from different varieties. J Sci Food Agr 34: $307-310$.

3. Yamanishi T, Kobayashi AH, Uchida A, Mori S, Ohsawa, et al. (1968) Comparison of various types of black tea. Agr Biol Chem 32: 379-386.

4. Cloughley JB, Ellis RT, Pelnlington S, Humphrey P (1982) Volatile constituentls of some Central Africa Black-tea clones. J Agr Food Chem 80: 842-884.

5. Howard GE (1978) The volatile constituents of tea. Food Chem 4: 79-106.

6. Bala Subramaniam In Tea in India, Publication and Information Directorate, CSIR, and Wiley Eastern Ltd., New Delhi, India (1995).

7. Dreosti IE, Wargovich MJ, Yang CS (1997) Inhibition of carcinogenesis by tea: the evidence from experimental studies. Crit Rev Food Sci 37: 761-770.

8. Tijburg LBM, Mattern T, Folts JD, Weisgerber UM, Katan MB (1997) Tea flavonoides and cardiovascular diseases: a review. Crit Rev Food Sci 37: 771 -785 .

9. Wiseman SA, Balentine DA, Frei B (1997) Antioxidants in tea. Crit Rev Food Sci 37: $705-718$

10. Yang CS, Wang ZY (1993) Tea and cancer. J Natl Cancer Inst 85: 1038 -1049.

11. Yang GY, Liao J, Kim K, Yurkow EJ, Yang CS (1998) Inhibition of growth and induction of apoptosis in human cancer cell lines by tea polyphenols. Carcinogenesis 19: 611-616.

12. Gulati A, Ravindranath SD (1996) Seasonal variation in quality of Kangra tea [Camellia sinensis (L.) O. Kuntze] in Himachal Pradesh. J Sci Food Agr 71 231-236.

13. Gulati A, Tamang MB, Ravindranath SD (1999) Clonal variation in quality related biochemicals in Kangra tea [Camellia sinensis (L.) O. Kuntze]. Journal of Plantation Crops 27: 175-178.

14. Ullah MR (1985) Aroma constituents of Assam and China hybrid teas and their manifestation during tea processing. Two and a Bud 32: 60-62.

15. Roberts EAH, Smith RF (1963) The phenolic substances of manufactured tea IX.- - the spectrophotometric evaluation of tea liquors. J Sci Food Agric 14: 687 700

16. Biswas AK, Biswas AK (1971) Biological and chemical factors affecting the valuations of North-East Indian plains teas: II. Statistical evaluation of the biochemical constituents and their effects on briskness, quality, and cash valuations of black teas. J Sci Food Agric 22: 196-204

17. Biswas AK, Sankar AR, Biswas AK (1973) Biological and chemical factors affecting the valuations of North-East Indian plains teas: III. Statistical evaluation of the biochemical constituents and their effects on colour, brightness and strength of black teas. J Sci Food Agric 24: 1457-1477.

18. Ullah MR (1984) A reappraisal of withering process in black tea manufacture 1. Physical and Chemical withers and their effects on tea liquors. Two and a Bud 31: 24-27.

19. Mahanta PK (1988) Color and flavour characteristics of made tea. In Linskens H.F. et al. (eds.) Modern Methods of plant Analysis. New series volume 8 Springer, Berlin 220-295.

20. Owuor PO, Obanda M (1998) The changes in black tea quality due to variations of plucking standard and fermentation time. Food Chem 61: 435-441.

21. AOAC International Official Methods of Analysis, Estimation of moisture, 17th edition Dr. William Horwitz,Editior, 2000a vol.2, Chapter 30 , p.12.

22. AOAC International Official Methods of Analysis, 17th edition Dr. William Horwitz, Editior, 2000b vol.2, Chapter 44, p.3.

23. AOAC International Official Methods of Analysis, Water extract of tea. 17th edition Dr. William Horwitz, Editior, 2000c vol.2, Chapter 30, p.12.

24. Ramaswamy $V$ (1995) An instrument for determining the free flow bulk density of black tea. The Planters Chronicle 90: 323-325.

25. Pura Naik J, Nagalakshmi S (1997) Determination of caffeine in tea products by an improved high-performance liquid chromatography method. J Agr Food Chem 45: 3973-3975. 
Citation: Borse BB, Jagan Mohan Rao L (2012) Novel Bio-Chemical Profiling of Indian Black Teas with Reference to Quality Parameters. J Bioequiv Availab S14. doi:10.4172/jbb.S14-004

Page 16 of 16

26. Ullah MR (1986) A rapid procedure for estimating theaflavins and thearubigins of black tea. Two and a Bud 33: 46-48.

27. Bailey RG, Nursten HE, McDowell I (1991) Comparative study of the reversedphase high-performance liquid chromatography of black tea liquors with special reference to thearubigins. J Chromatogr 542: 115-128.

28. Likens ST, Nickerson GB (1964) In Proceedings of the American Society for Brewery Chemists 5: $5-13$.

29. Adams RP (2001) Identification of essential oil components by gas chromatography /quadrupole mass spectroscopy, Allured Publishing Corporation, Illinois, USA. 41-442.

30. Davies W (1990) Gas chromatographic retention indices of monoterpenes and sesquiterpenes on methyl silicone and carbowax $20 \mathrm{M}$ phases. J Chromatogr 503: 1-24.
31. Jennings W, Shibamoto $T$ (1980) Qualitative analysis of flavour and fragrance volatiles by glass capillary gas chromatography, Academic Press, New York. 29.

32. Baruah S, Hazarika M, Mahanta PK, Horita H, Murai T (1986) Effect of plucking intervals on the chemical constituents of СTC black teas. Agric Biol Chem 50: 1039-1041.

33. Mahanta PK, Baruah S, Owuor PO, Murai T (1988) Flavour volatiles of Assam CTC black teas manufactured from different plucking standards and orthodox teas manufactured from different altitudes of Darjeeling. J Sci Food Agric 45 317-324.

34. Yamanishi T, Botheju WS, De Silva JM (1989) An index for assessing the quality of Uva seasonal black tea. Sri Lanka Journal of Tea Science 58: 40-49. 